\title{
A combined GIS-MCDA approach to prioritize stream water quality interventions, based on the contamination risk and intervention complexity
}

\author{
A.C.P. Fernandes ${ }^{\text {a,* }}$, D.P.S. Terêncio ${ }^{\text {a,b }}$, F.A.L. Pacheco ${ }^{\text {b }}$, L.F. Sanches Fernandes ${ }^{a}$ \\ a Centro de Investigação e Tecnologias Agroambientais e Biológicas, Universidade de Trás-os-Montes e Alto Douro, Ap 1013, 5001-801 Vila Real, Portugal \\ b Centro de Química de Vila Real, Universidade de Trás-os-Montes e Alto Douro, Ap 1013, 5001-801 Vila Real, Portugal
}

\section{H I G H L I G H T S}

- The majority of Ave river basin surface waters are under low quality.

- Contamination risk and intervention complexity were accessed by GISMCDA.

- A "cost-benefit" decision analyses allowed ranking catchments for intervention.

- The prioritization spanned 248 catchments.

- Catchments under a good status were mostly ranked under low intervention priority.

\section{A R T I C L E I N F O}

\section{Article history:}

Received 26 April 2021

Received in revised form 20 July 2021

Accepted 24 July 2021

Available online 27 July 2021

Editor: Damia Barcelo

\section{Keywords:}

GIS-MCDA

Water quality

Ecological status

Chemical status

Landscape metrics

Pollution
G R A P H I C A L A B S T R A C T

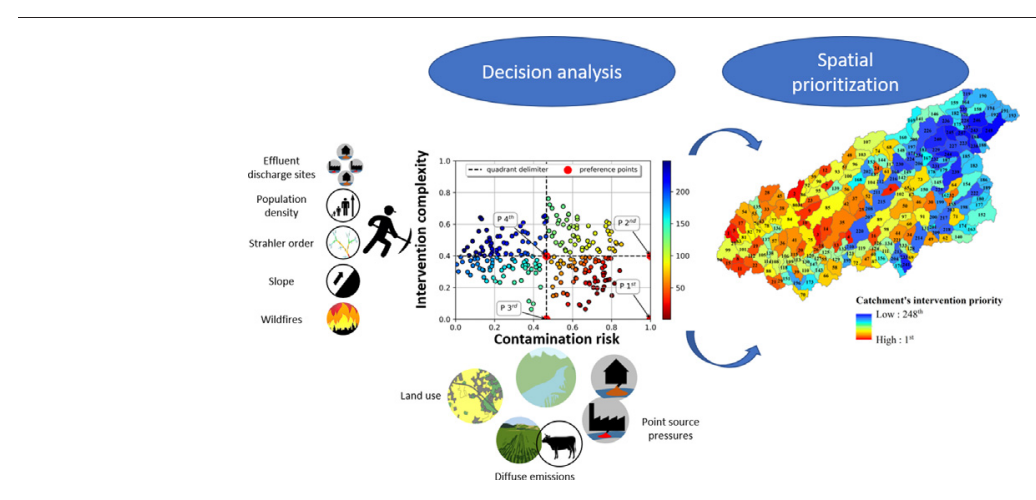

\begin{abstract}
A B S T R A C T
Water management decisions are complex ever since they are dependent on adopted politics, social objectives, environmental impacts, and economic determinants. To adequately address hydric resources issues, it is crucial to rely on scientific data and models guiding decision-makers. The present study brings a new methodology, consisting of a combined GIS-MCDA, to prioritize catchments that require environmental interventions to improve surface water quality. A Portuguese catchment, Ave River Basin, was selected to test this methodology due to the low water quality. First, it was calculated the contamination risk of each catchment, based on a GISMCDA using point source pressures, landscape metrics, and diffuse emissions as criteria. This analysis was compared to local data of ecological and chemical status through ANOVA and the Tukey test. The results showed the efficiency of the method since the contamination risk was lower for catchments under a good status and higher in catchments with a lower classification. In a second task, it was calculated the intervention complexity using a different GIS-MCDA. For this approach, it was chosen five criteria that condition environmental interventions, population density, slope, percentage of burned areas, Strahler order, and the number of effluent discharge sites. Both multicriteria methods were combined in a graphical analysis to rank the catchments intervention priority, subdividing the prioritization into four categories from 1st to 4th' giving a higher preference for catchments with high contamination risk and low intervention complexity. As a result, catchments with a good status were dominantly placed under low intervention priority, and catchments with a lower ecological status were classified as a high priority, 1 st and 2 nd. In total, 248 catchments were spatially ranked, which is an essential finding for decision-makers, that are willing to safeguard the catchment water quality.
\end{abstract}

(c) 2021 Elsevier B.V. All rights reserved.

\footnotetext{
* Corresponding author.

E-mail address: acpf91@utad.pt (A.C.P. Fernandes).
} 


\section{Introduction}

Water is a crucial element linked to socio-economic development. Both quality and availability are essential for human survival (Mehta, 2014). In a world with constant changes (Delpla et al., 2009; Vörösmarty et al., 2000), the management of hydric resources depends on interdisciplinary studies that aboard multiple challenges such as pollution sources, contamination effects, and even climate change. Which has been responsible for temperature changes (Fonseca and Santos, 2018; Martins et al., 2020), erratic stormflows (M. Santos et al., 2019), and diverse hydrological alterations (Fonseca and Santos, 2019; Hagemann et al., 2014), such as floods (Antwi-Agyei et al., 2017; Terêncio et al., 2020,2019 ). The degradation of hydric resources is caused by multiple threats commonly distinguished between point and non-point pollution sources (Conley et al., 2009; Wittmer et al., 2010). Concerning threats are responsible for contaminating hydric resources, which comprise a wide range of substances, including nutrients, micropollutants, and heavy metals (Destouni et al., 2017; Ippolito et al., 2015; Spycher et al., 2018). Even nowadays, different forms of contaminations can be found (Karkman et al., 2018; Murphy et al., 2016; Schuwirth et al., 2018; Sousa et al., 2020), requiring continuous research to bring relevant information to decision-makers (Mello et al., 2018; Lima, 2008). Water management decisions are complex (Pahl-Wostl, 2007) and require deep awareness of cause-effect interactions between pollution sources and surface waters (Dwivedi and Shikha, 2016). It is necessary to understand that surface waters are complex systems (Vannote et al., 1980), vulnerable to multiple natural and anthropogenic phenomena (Khatri and Tyagi, 2015; Voza et al., 2015) that can end up transporting contaminants to rivers (Reid et al., 2019). As well for such reasons, the European Union (EU) embraced the Water Framework Directive (WFD) (EC, 2000) as a framework for water policy, addressing the management of hydric resources in terms of quantity and quality. One of the instruments of the implementation of the WFD is the River Basin Management Plans (RBMP), which are strategic reports that propose measures for achieving the WFD goals (Skoulikaris and Zafirakou, 2019), including the control of pollution sources.

Wastewater treatment plants (WWTP) are designed to reduce the contaminant loads from sewage (Guadie et al., 2021; Miller, 2019). In these stations, wastewaters are treated to release the effluents into rivers under legislated thresholds of contaminant concentrations, which should be environmentally sustainable (Pérez Andrés et al., 2019). Still, the released effluents decrease the water quality of rivers which defines WWTP discharge sites as point source pressures (Rattan et al., 2020). Also, concerning hydric resources, other types of pollution sources are threatening, particularly diffuse pressures (Mockler et al., 2017). Typically, are large fields containing contaminants such as agricultural areas or livestock farms. Due to rainfall, contaminants are transported to groundwater due to soil infiltration (Pacheco et al., 2018), also due to surface runoff, pollutants are carried to rivers (Mellander et al., 2015). In addition, contaminants in groundwaters can be transported to surface waters since both are linked (Kazakis et al., 2020). Livestock farms are a source of organic pollution (Zhang et al., 2020) with loads of nitrogen (W. Li et al., 2020; Z. Li et al., 2020), phosphorus (Withers and Jarvis, 1998), and bacteria (F. Santos et al., 2019). In agricultural fields, pesticides (Jayasumana et al., 2014) and fertilizers (Zörb et al., 2014) are the main cause of pollution. A natural mechanism of protection against the transport of contaminants is the presence of forested areas, which can retain part of the contaminant flow, acting as sinks of contamination (Nilsson and Svedmark, 2002; Warrington et al., 2017). These vegetation barriers are fundamental to safeguard rivers when placed in the borders as riparian vegetation (Fernandes et al., 2011). In this perspective of interactions, it stands out that land use has an intrinsic relation with water quality (Baker, 2003). Not only in terms of composition but also configuration (Uuemaa et al., 2007), this relation was addressed by different authors with landscape metrics (Zhao et al., 2011). The calculation of these indicators can be made through multiple software, such as vLATE (Lang and
Tiede, 2003), PatchAnalyst (Rempel et al., 2012), DYD (Zaragozí et al., 2012), FRAGSTATS (Raines, 2002), and still, new software has been developed (Adamczyk and Tiede, 2017). Each software has different advantages that depend on the researcher's necessities and study subjects. In the scope of water quality, researchers have found interesting results, such as in catchments with a high diversity of land uses the contamination increases (Lee et al., 2009; Uuemaa et al., 2007), fragmented forests do not filter pollutants effectively (Lee et al., 2009), sizeable agricultural fields increase the concentration of nutrients (Yu et al., 2016), but complex landscapes can retain more nutrients (Lee et al., 2009). These conclusions can be different among authors (Johnson et al., 1997; Zhang et al., 2019) due to the differences between study areas, study design (Schiff and Benoit, 2007), and also the interactions are dependent on seasonal and scale effects (Wu and Lu, 2021).

To formally address water quality surges the necessity of using advanced monitoring techniques (Varotsos et al., 2021, 2020, 2019), and apply them to models that can expose the problem (Krapivin et al., 2021, 2017; Varotsos and Krapivin, 2019, 2018). Models are commonly distinguished between two types, statistical or physical (Thakur, 2012). In the first type, the cause-effect interactions are expressed by the dataset. In contrast, in physical, the interactions are already defined by the model (Loucks and van Beek, 2017) according to biological, chemical, and physical processes (Nas and Nas, 2009). Decision-makers environmental actions are prompted by models and experimental tests to assess human and ecological hazards (Huang et al., 2011). The decision-making process is complex and requires multidisciplinary knowledge based not only on environmental phenomena but also on politics and ethics (Huang et al., 2011). In this context, the Multicriteria Decision Analysis (MCDA) brings a response that consists of examining alternatives to solve problems using several criteria related to the decision object (Francisco et al., 2008), carrying cost/benefit information to rank possible options (Huang et al., 2011). With the advent of Geographic Information Systems (GIS), MCDA has been combined (Mentzafou et al., 2019) to adopt methodologies that are spatially dependent (Malczewski, 2010).

In different MCDA applications, authors have used different methodologies, such as PROMETHEE (Brans and Mareschal, 2016), ELECTRE (Govindan and Jepsen, 2016; Yu et al., 2018), MAUT (De Montis et al., 2004), and continuously new approaches have been developed (Benítez and Liern, 2021). Besides, the Analytic Hierarchy Process (AHP) is one of the oldest methods (Saaty, 1980) is still the most used by researchers and decision-makers (Russo and Camanho, 2015), even in studies within an environmental scope (Huang et al., 2011). Different MCDA methods have been applied in the surface water quality context with interesting results and applicable methodologies. Different studies comprise multiple objectives such as evaluating intervention options to achieve a good ecological status (McInnes et al., 2016), prioritize conservation areas (Mello et al., 2018), prioritize regions for water quality monitoring (Mentzafou et al., 2019), or mapping the ecological vulnerability (Ofosu et al., 2020).

To support decision-makers, the present study takes a step forward by implementing an innovative decision process to prioritize catchments based on the necessity and difficulty to apply interventions to improve water quality. In standard approaches, the prioritization of locations for environmental interventions is only based on the necessity of intervention, accessed by pollution sources or the detection of high contaminant concentrations. In the present study, the necessity was approached by a GIS-MCDA and compared with water quality data to test if the necessity of intervention was concordant to the surface waters ecological and chemical status. To properly prioritize catchments for intervention, it was implemented an innovative concept which is the intervention complexity, also accessed by a GIS-MCDA. By combining both, it is given the prioritization rank, based on the principle that catchments with low complexity and high necessity should be the first ones to intervene. This methodology was applied in an urbanized river basin, the Ave River basin, which has been the target of many studies due to 
the local pollution problems. Concerning threats lead researchers to develop physical (Fonseca et al., 2018) and statistical models (A.C.P. Fernandes et al., 2019) to evaluate surface water quality. In this context, authors have approached the necessity of developing decision processes based on multicriteria methodologies to manage hydric resources (Terêncio et al., 2017). The river basin has multiple contamination problems (SNIAMB, 2016), requiring several environmental interventions in different regions to approach the WFD goals (A.C.P. Fernandes et al., 2019; Fernandes et al., 2018; Ferreira et al., 2017).

\section{Methodology}

\subsection{Study area}

Ave River Basin (ARB), presented in Fig. 1, is located in the Northwest region of Portugal. The altitude varies from 0 to $1253 \mathrm{~m}$, where the highest peak is found in the headwaters, located in the Cabreira mountains. According to Couto et al., 2018, the annual average river flow is around $40 \mathrm{~m}^{3} / \mathrm{s}$. The average temperature ranges from 12 to $15{ }^{\circ} \mathrm{C}$ (Ferreira et al., 2017), and the annual rainfall varies along to topography from 2000 to $1200 \mathrm{~mm} /$ year (Ferreira et al., 2017) but in average is $1522 \mathrm{~mm} /$ year (A.C.P. Fernandes et al., 2019). The Ave River extends for $100 \mathrm{~km}$ until the Atlantic Ocean outlet. The drainage area occupies 1300 $\mathrm{km}^{2}$, and the main tributaries are Este and Vizela rivers, with drainage areas that hold $250 \mathrm{~km}^{2}$ and $232 \mathrm{~km}^{2}$, respectively. According to the Portuguese RBMP (PGRH, 2016a), ARB is located in the hydrographic management unit number 2, Fig. 1(B), which is shared with Cávado and Leça River basins. These delimitate ARB by the north and south, respectively, to the east is located the Douro River basin, which belongs to the hydrographic management unit number 3.
The ARB water quality is compromised by many threats since in the river basin is practised intensive agriculture, livestock production, and high industrial activity (Rocha et al., 2013). During the fifties, hundreds of environmental transgressions were reported due to the lack of sanitation and industrial activities (Costa, 2008). In early studies, the concentration of heavy metals was preoccupying (measured during 1993) that were released from multiple industries (Araújo et al., 1998; Gonçalves et al., 1992; Soares et al., 1999). By the end of the century, the Portuguese government embraced a remediation plan that encompassed the construction of treatment plants (Ferreira et al., 2017). As a result, the concentration of heavy metals decreased (Alves et al., 2009), improving the water quality (de Vasconcelos, 2015). Besides this improvement, the river still shows high levels of pollution (Amporto, 2009), which has caught the attention of several researchers. Although initial studies focused on heavy metal contamination, other concerns arose in the basin, leading other authors to study different contamination forms. High concentrations of nutrients were detected in the river basin, which was compromising the aquatic biodiversity (Pascoal et al., 2005b), not only due to effluent discharges but also because of the agricultural activity, as other authors have also reported (Dunck et al., 2015; Peixoto et al., 2013). The persistent nutrient concentration deteriorated the ecological status, predominantly in the proximity to the river mouth (Pascoal et al., 2005a, 2003). Also, livestock effects became concerning (Ribeiro et al., 2016), which alarmed many authors to focus their studies on the impacts of diffuse pollution (Fonseca et al., 2018; Terêncio et al., 2017). The presence of multiple threats has alarmed many authors, which required the necessity of developing multivariate studies to compare the effects of different pollution sources (A.C.P. Fernandes et al., 2019; Fernandes et al., 2018; Ferreira et al., 2017), identifying livestock and point source pressures as dominant
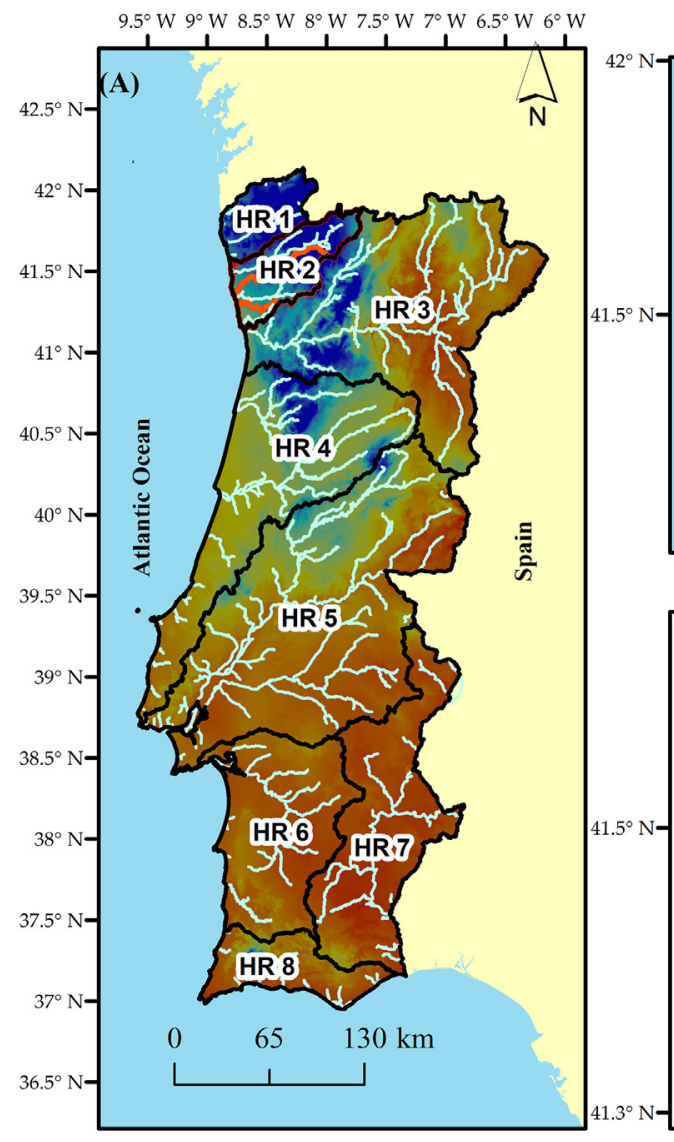
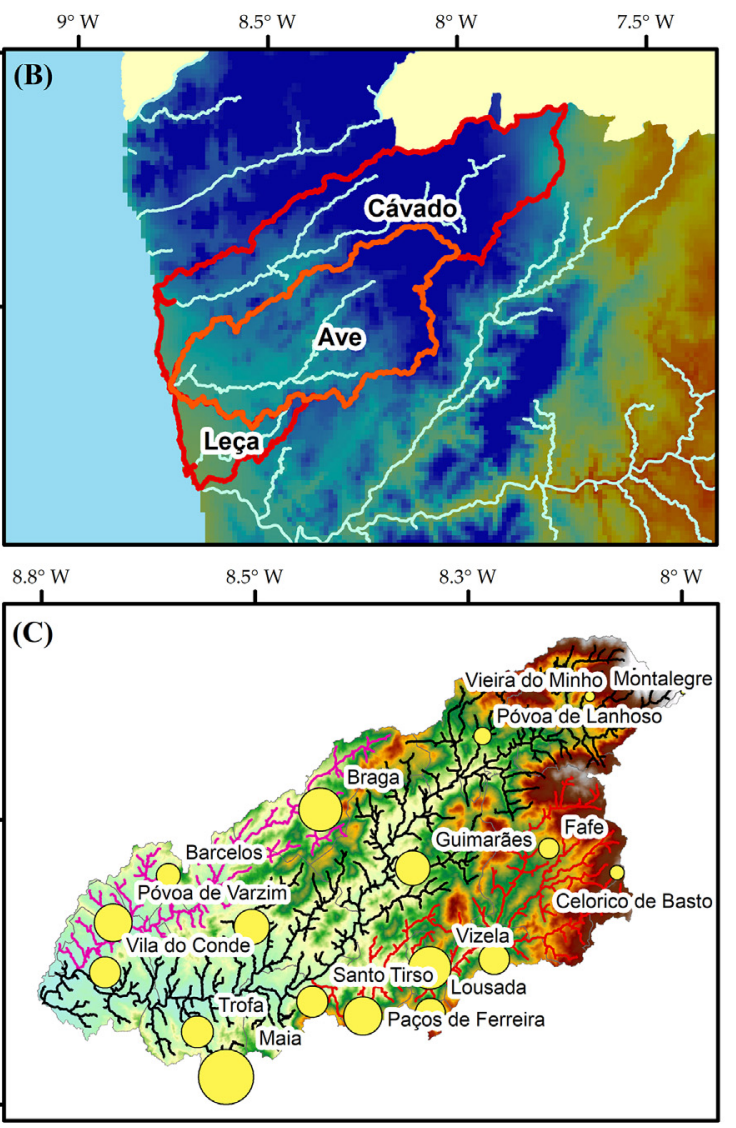

Legend (A) and (B)

$\square$ Hydrographic Regions Portuguese Rivers Ave River Basin Hydrographic Region 2 Spain

Rainfall (mm/year)

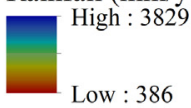

Ocean

\section{Legend (C)}

Population density (inhabitants $/ \mathrm{km}^{2}$ )

- 10

○ 100

1000

Drainage lines

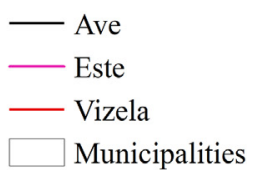

Elevation (meters)

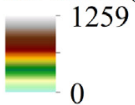

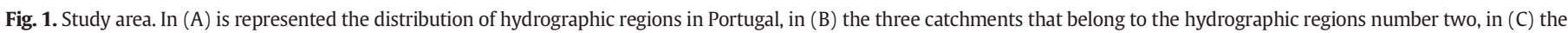
study area, Ave River Basin. 
threats. Still, in further studies, it was found that the land-use composition and configuration have a pivotal role in ARB water quality (A. Fernandes et al., 2019a; A.C.P. Fernandes et al., 2020a, 2020b).

\subsection{Conceptual framework model}

The purpose of the present study is to present a decision analysis method to support decision-makers in prioritizing catchment interventions to improve water quality. The methodology was applied to ARB since it is one of the Portuguese catchments that highlights surface water pollution. This decision analysis was subdivided into three objectives, as presented in Fig. 2. The first objective was to identify the contamination risk (CR) of each catchment. This analysis was performed by using multicriteria decision analysis (MCDA) weighted by the Analytical Hierarchy Process (AHP). This first analysis relied on variables that indicate the pollution of surface waters, including diffuse and point source pressures and landscape metrics. The second objective consisted of identifying catchments intervention complexity. This

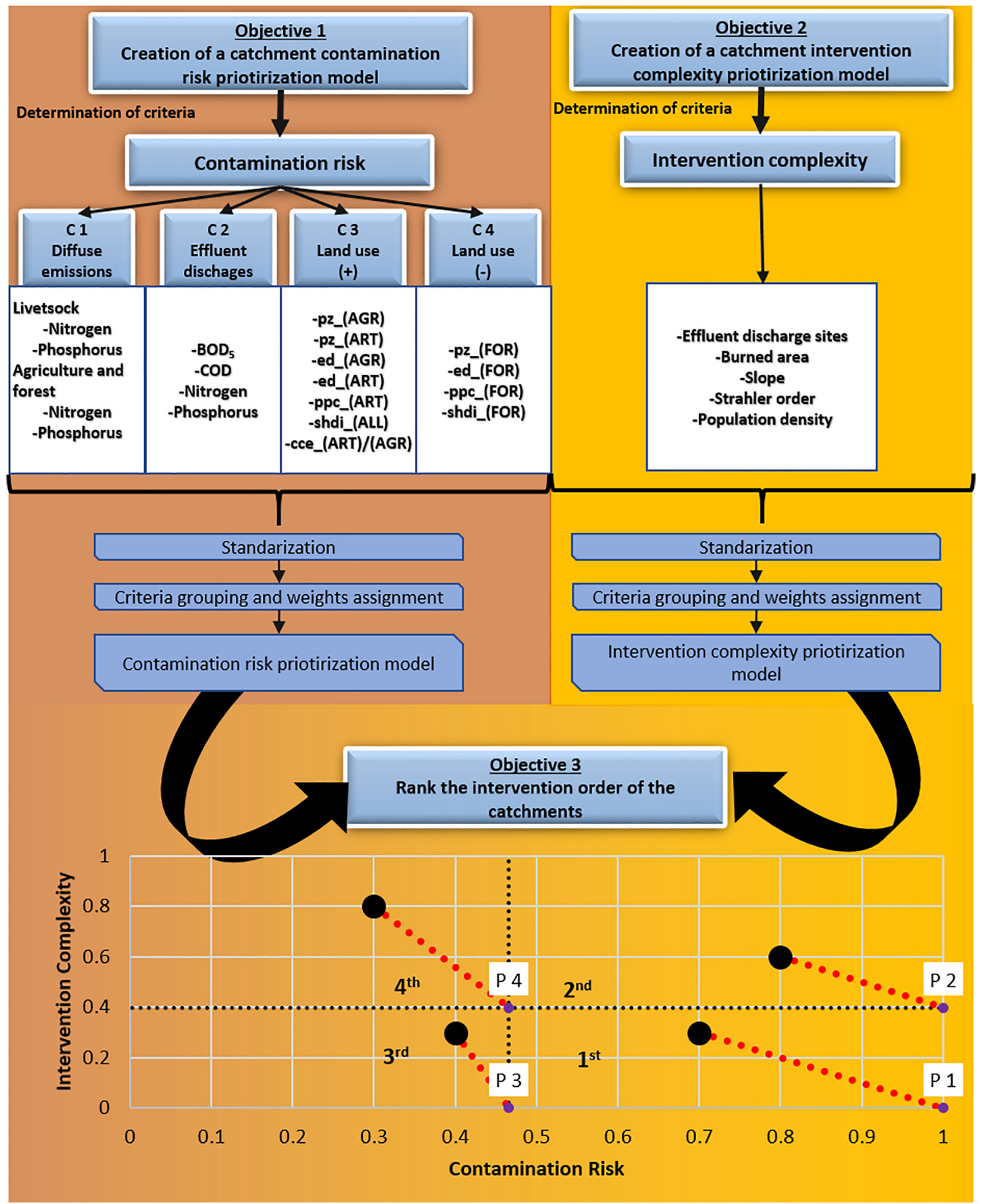

Fig. 2. Flowchart representing the main steps of the study, two multicriteria decision analyses to fulfil objectives 1 and 2 , and graphical decision analysis, objective 3 . 
analysis was made to identify how difficult it is to apply any environmental interventions that can improve water quality, regarded to land-use changes, reduction of the point source and diffuse emissions. The intervention complexity (IC) was also approached by using an MCDA, weighted by AHP. The third and final objective consisted of combining the risk and complexity to prioritize catchments for intervention to reduce the contamination potential to improve the ARB water quality through graphical analysis.

\subsection{Data processing}

Since the present study was applied at a catchment scale, using spatial data, the dataset preparation was performed using ArcMap (ESRI, 2010). With the digital elevation model, downloaded from the European Environmental Agency (EEA) (EEA, 2021) with a resolution of 25 per $25 \mathrm{~m}$, it was calculated the ARB boundaries, drainage lines, and sub-catchments, using the ArcHydro tool package (ESRI, 2012). With this procedure, the ARB was subdivided into 248 subcatchments, Fig. 3(A). Besides the river basin was split into subcatchments, the $\mathrm{CR}$ analysis was performed by encompassing each sub-catchment from the outlet to the entire upstream area, Fig. 3(B). The authors adopted this procedure because the pollution of surface waters spreads from upstream to downstream catchments, causing a cumulative effect (Vannote et al., 1980). The data of point source and diffuse pressures was ceded from the Portuguese Environmental Agency (APA), which can be visualized in the National Environmental Information System (SNIAMB, 2016). The point source pressure data (PSP) was ceded in a point shapefile, containing the annual flow of biological and chemical oxygen demands (BOD and COD) and total nitrogen $(\mathrm{N})$ and phosphorous $(\mathrm{P})$, released from urban and industrial treatment stations, with all the data expressed in tons per year. This dataset was intersected with the drainage areas, and it was used in the CR model using the total annual flow per year per the square kilometres of each drainage area. The diffuse pressures dataset was ceded in the form of polygon shapefiles containing the estimated flows of $\mathrm{N}$ and $\mathrm{P}$ from livestock and agriculture and forestry in kilograms per year. These values were intersected with each drainage area to implement in the CR model, in kilograms per year per square kilometre. The landscape metrics that composed CR were divided into two groups, metrics associated to land uses that degrade water quality $(\mathrm{M}+)$, while the other group is based on metrics related to the decrease of $C R(M-)$. The metrics calculation required the Portuguese land cover map from 2015 in the shapefile format (DGTerritório, 2018). The landscape metrics were calculated for the drainage areas with a python toolbox (Adamczyk and Tiede, 2017). The chosen metrics were the area percentage (pz), density of edges (ed), percentage of land use patches (ppc), Shannon's diversity index (shdi), and the percentage of edges that are shared between two land-use types (cce). For the group of metrics $M+$, the metrics were calculated for agricultural areas (AGR) and artificial surfaces (ART). For these two types of land use, all the metrics were calculated, except for shdi that was calculated for all land uses, defined as shdi_(ALL). For the group of metrics $\mathrm{M}-$, it was calculated all landscape metrics that were related to forestry and semi-natural areas, pz, ed., ppc and also the shdi. The IC was composed of 5 variables, slope, population density, Strahler order, burned areas, and the number of effluent discharge points. The last variable was calculated for each sub-catchment considering all the upstream area, while for the other four, it was calculated only for the sub-catchment, as shown in Fig. 3. The slope was calculated in percentage using the digital elevation model as input for the "Slope" tool in ArcMap. The population density data was downloaded from the National Statistics institute website in the form of a shapefile (INE, 2014) and converted into a raster file to apply the tool "zonal statistics as table" to extract the average population density in each catchment. The Strahler order was identified for the respective drainage line of each catchment with the "Order" tool. For each catchment, it was also calculated the burned area from 2015 to 2020. The necessary data for this procedure was downloaded from the Portuguese Institute of Nature and Forests Preservation in the shapefile format (ICNF, 2021). The number of effluent discharge points that was intersected between the drainage areas and the point source pressures shapefile. All the data was joined in a single excel file as input for the multicriteria analysis, available in the supplementary material.

\subsection{Prioritization procedure}

The prepared excel worksheet was used as an input for each MCDA model, CR and IC. The preparation of these models followed a similar methodology used by another author (Terêncio et al., 2021). The procedure consisted of the following tasks, determination of criteria, data standardization, weights coefficient calculation, criteria grouping, weights assignment, and prioritization of catchments, Fig. 2. The used criteria in the CR were point source pressures (PSP), diffuse pressures (DP), landscape metrics that increase the contamination risk $(\mathrm{M}+)$, and landscape metrics that decrease the contamination risk $(\mathrm{M}-)$. The sub-criteria for PSP were the calculated discharges of $\mathrm{BOD}_{5}, \mathrm{COD}$,

(A)
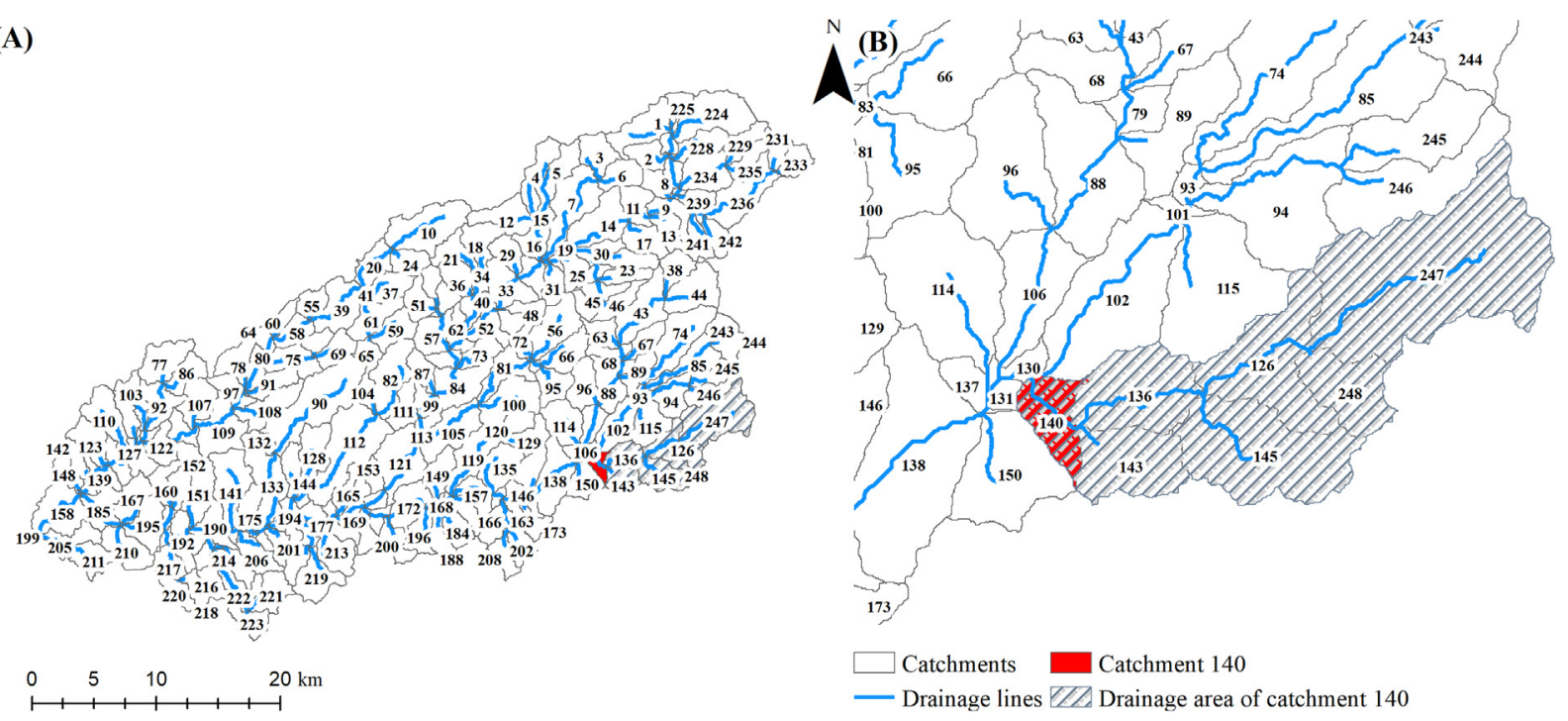

Fig. 3. (A) Ave river basin division into sub-catchments; (B) example of a catchment and respective drainage area. 
$\mathrm{N}$ and $\mathrm{P}$ from effluent discharge points. For DP, it was also attributed four sub-criteria, in this case, the diffuse emissions from $\mathrm{N}$ and $\mathrm{P}$ from livestock and agriculture activities. The landscape metrics sub-criteria of $M+$ was composed by shdi, cce_(ART)/(AGR), pz_(ART), pz_(AGR), ed_(ART), ed_(AGR), ppc_(ART) The criteria $M-$ was formed by four sub-criteria, pz_(FOR), ed_(FOR), ppc_(FOR) and shdi_(FOR). The CR model was only composed of criteria: slope, population density, Strahler order, burned areas, and effluent discharge points. The input variables were ranked from the highest to the lowest and then standardized from 0 (lowest value) to 1 (highest value). The variables that compose the sub-criteria of $(\mathrm{M}-)$ were normalized in inverse rankings, 0 the highest and 1 for the lowest. The weighting of criteria and sub-criteria was applied using AHP (Saaty, 2000), implemented in an excel template developed by other authors (Goepel, 2013). The AHP process is an approach that uses pairwise comparisons of criteria, which indicates how much important is a criterion from another (Huang et al., 2011). In this process, consistency was verified by evaluating the consistency ratio, which must be lower than $10 \%$ (Saaty, 2008). For each group of criteria/sub-criteria, it was attributed weights that resulted in a sum equal to 1 . Due to the standardization procedure, each score can vary from 0 to 1 . For a detailed review of MCDA, readers may consult (Murray, 2002). All the calculation for the weighting criteria is presented in the supplementary material.

For the final objective, it was made a graphical analysis based on CR and $\mathrm{CI}$ scores. First, all the catchments were plotted in a bi-dimensional graph, where the $\mathrm{x}$-axis is the $\mathrm{CR}$, and the $\mathrm{y}$-axis is the IC. Then the graphic was divided into four quadrants, as the vertical splitter was the average score of CR and the horizontal splitter the average score of IC. Each quadrant was defined as the chosen priority of intervention, $1 \mathrm{stQ}, 2 \mathrm{ndQ}$ 3rdQ, and 4thQ. This means that all the catchments that are in the 1stQ have priority over the others, the ones that are placed in the 2ndQ have priority to the 3rdQ and 4 thQ and so on. The 1 st $Q$ is vertically delimited by the maximum $\mathrm{CR}$ (equal to 1 ) and the average, horizontally by the minimum (equal to 0 ) and the average IC. The 2nd Q has the same vertical limits but horizontally delimited by the average and maximum IC. The 3rd Q is horizontally limited by the minimum and average IC, and vertically by the minimum and average $C R$. The 4th $Q$ has the same vertical limits but is horizontally delimited by the average and maximum IC. This categorization of sub-catchments in quadrants was based on the principle that it should be prioritized intervention in catchments that have the highest CR but the lowest IC. With the data divided into four ranking categories, it was also necessary to prioritize the catchments inside the quadrants. This second-ranking procedure was based on the Euclidean distance of the IC and CR scores to the optimal point inside the quadrant, which is with the maximum $\mathrm{CR}$ and minimum IC, as the distance decreases, the priority increases.

In addition, the results were compared with the ecological and chemical status of ARB surface waters, also available on the APA website (SNIAMB, 2016). This comparison was made to confirm if the contamination risk calculation was concordant to the water quality of subcatchments. According to the WFD, the Environmental Quality Ratio $(E Q R)$ is the division of the observed biological value by the reference biological value, which in this case was evaluated for the ecological status (László et al., 2007). It was also compared the CR with 12 measurements of a Portuguese macroinvertebrate index $\left(\mathrm{IPtI}_{\mathrm{N}}\right)$, reported in a previous study (A. Fernandes et al., 2019a). The ecological and chemical statuses were compared with the CR using one-way ANOVA and Tukey test since the status evaluation is a categorical variable. The $\operatorname{IPtI}_{N}$ was compared in a scatter plot since it is a numerical indicator that varies from 0 to 1.05 (INAG, 2009), where the score 0 is for polluted sites that have no diversity of macroinvertebrates, while the maximum score is often attributed to sites with minimal pollution.

Besides the present methodology was applied to a single river basin, it can be applied to others. The applicability is only dependent on the access to enough data to proceed with all the calculations regarding the land use map, digital elevation model, burned areas, point source and diffuse emissions, population density. The authors also recommend to verify if the calculated contamination risk is according to the water quality status. All the calculations for AHP and intervention priority are available in excel worksheets in the supplementary material.

\section{Results}

\subsection{Contamination risk and intervention complexity}

The spatial distribution of all the input variables for the two GISMCDA (CR and IC) is portrayed in Fig. 4(A) to (J). Diffuse nutrient emissions estimated by official authorities that were transposed to the ARB drainage areas are presented in Fig. 4(A) to (D), in total loads of nitrogen and phosphorous per $\mathrm{km}^{2}$ per year from livestock (LS), agriculture and forestry (AgF). As shown, loads of nutrients are much higher from livestock than from agricultural fields, and both diffuse emissions seem to be more clustered near the ARB outlet. The number of effluent discharge points from urban and industrial sources is shown in Fig. 4(I) and the number of effluent discharge points that affect each catchment. Total loads of $\mathrm{BOD}_{5}, \mathrm{COD}$, Nitrogen and Phosphorous from point source pressures for each drainage area are presented in Fig. 4(E) to (H), in ton per $\mathrm{km}^{2}$ per year. The results show that the catchments with the highest Strahler order, Fig. 4(L), have the highest contaminant flows. This can be seen in orange, Fig. 4(E) and (F) and in yellow/orange Fig. 4(G) and $(\mathrm{H})$, which correspond to the main rivers of ARB, Ave, Este, and Vizela. Some scattered catchments in red are catchments with high loads of effluent discharge. The percentage of each burned area from 2015 to 2020 is illustrated in Fig. 4(I). The wildfires are more frequent in the upstream area of ARB due to the dominance of forested areas. According to the slope map, Fig. $4(\mathrm{~K})$ in the areas with high burned areas are also shown the hills of Cabreira mountains that have the highest slope, besides along the river basin other scattered regions have a high slope. The population density was already calculated for ARB in previous studies for each parish (a total of 345). For the present study, a more detailed analysis was performed by calculating the population density for each census sub-section (a total of 15,191 in ARB), as presented in Fig. 4 (M). The resulting raster file was used to calculate the average population density in each catchment. Fig. $4(\mathrm{~N})$ depicts the distribution of land uses across the river basin, where the dominance of forestry in the upstream area and corresponding urban areas with high population density locations, Fig. 4(M). To check the attributed value of each landscape metric and other variables, please check the supplementary material, all the data was compiled in an excel worksheet, and the attributed values for each catchment and drainage areas, identified in Fig. 3(A). The created Excel file served as input for CR and IC calculation. The weights of each model were calculated by three authors using AHP. The pairwise comparisons were based on previous works in the ARB within an environmental scope (A.C.P. Fernandes et al., 2020a, 2020b, 2019; Fernandes et al., 2018). With this methodology, it was calculated all weights as is demonstrated in Table 1 . The weights were multiplied for each variable, and the product was summed. Obtained results of the CR and IC for each catchment are demonstrated in Fig. 5.

The contamination risk score varied from 0.850 to 0.006 (average of 0.47), which means that according to the adopted methodology, there are catchments with an almost null contamination risk, while others have a high score of $\mathrm{CR}$, the maximum found in ARB is 0.85 . Dominantly in the upstream areas of the Ave and Vizela rivers, the contamination risk is practically null due to the lack of contamination sources. But some scattered red and orange regions Fig. 5(A) can be seen along the river basin, but in the Este river is detected a high number of catchments with high contamination risk. The range of the IC score varies from 0.063 to 0.761 (average of 0.40 ), which means that there are catchments that are easier to apply interventions. Is seen a progressively downstream increase due to the Strahler order and cumulation of effluent discharge sites. But is noted that near the Este to Ave river connection, there is a cluster of zones marked in green with a low IC score. 


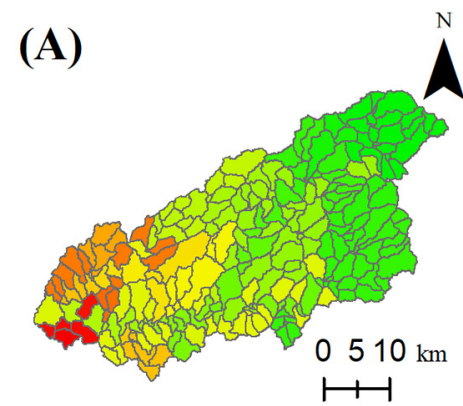

LS- Nitrogen (ton $/$ year $/ \mathrm{km}^{2}$ )

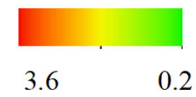

(E)

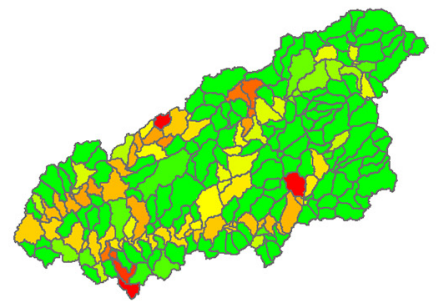

PSP- BOD 5 (ton/year $\left./ \mathrm{km}^{2}\right)$

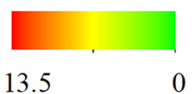

(I)

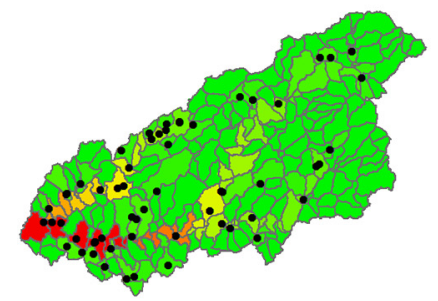

\section{Effluent discharge sites}

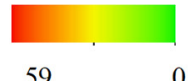

(M)

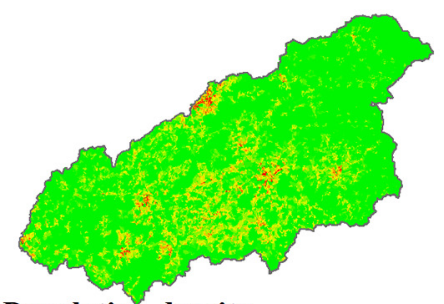

Population density (inhabitants $/ \mathbf{k m}^{2}$ )

61181
(B)

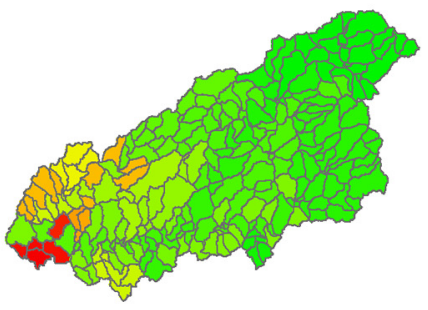

LS- Phosphorus (kg/year/km²)

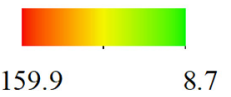

(F)

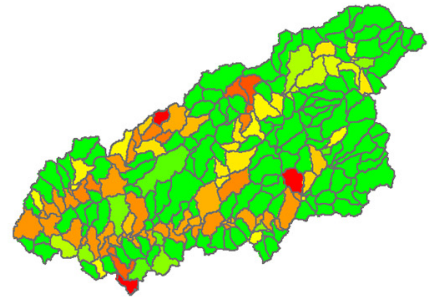

PSP- COD (ton $/$ year $/ \mathrm{km}^{2}$ )

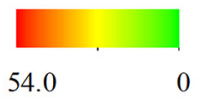

(J)
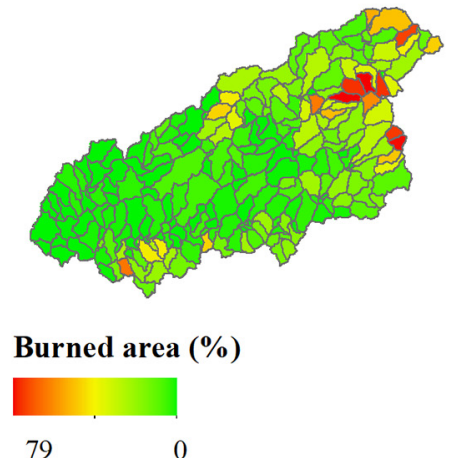

(N)

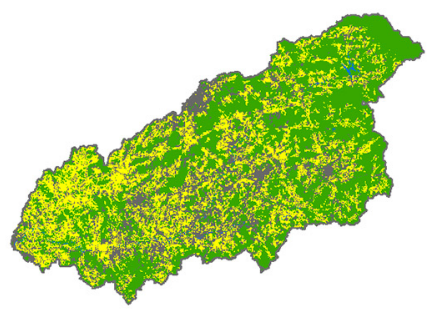

Land use

Agriculture Urban Forest Water
(C)

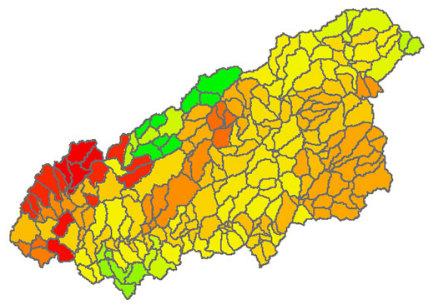

AgF- Nitrogen (kg/year/km²)

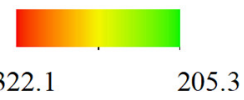

(G)

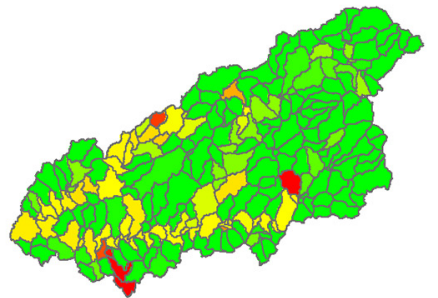

PSP- Nitrogen (ton/year $/ \mathbf{k m}^{2}$ )

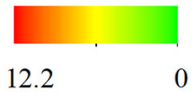

(K)
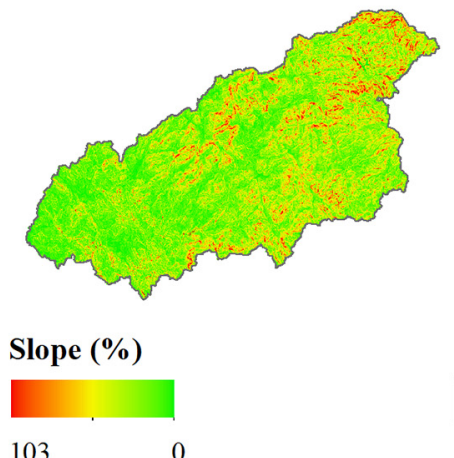

103

0
(D)

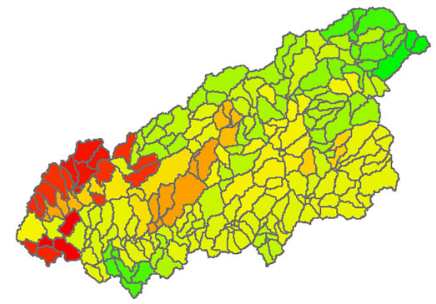

AgF- Phosphorus (kg/year/ $/ \mathrm{km}^{2}$ )

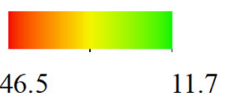

(H)

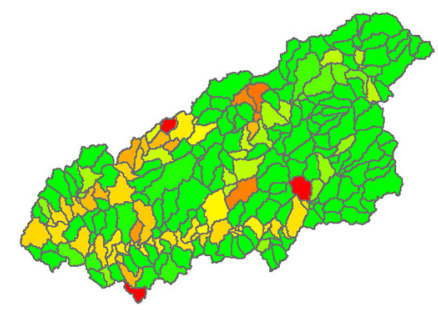

PSP- Phosphorus (ton/year $/ \mathrm{km}^{2}$ )

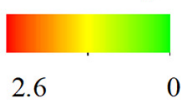

(L)
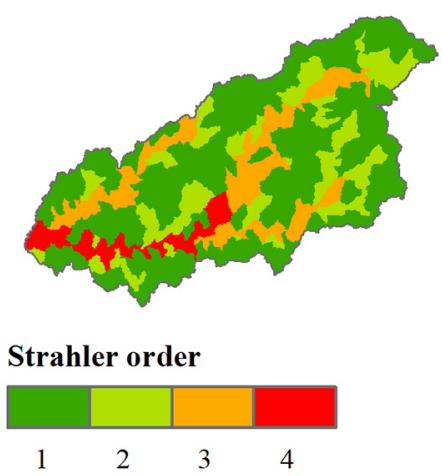

Fig. 4. Variables used for the calculation of the contamination risk and intervention complexity.

The calculation of the contamination risk is a crucial step in the presented methodology since this defines if a catchment is vulnerable to pollution sources. After calculating CR, the results were compared to water quality data to understand if the calculated risk was connected to the water quality. In this way, the CR was compared to the ecological, chemical status, and a Portuguese biological index, $\operatorname{IPtI}_{N}$, presented in Fig. 6. The ecological status can comprise five possible categories High, Good, Moderate, Poor and Bad (László et al., 2007), but as is seen in 
Table 1

Attributed weights of contamination risk and intervention complexity.

\begin{tabular}{lclc}
\hline Contamination risk & & & \\
\hline Diffuse emissions & \multirow{2}{*}{$8.9 \%$} & Livestock nitrogen & $40.7 \%$ \\
& & Livestock phosphorus & $27.5 \%$ \\
& & Agriculture and forest nitrogen & $17.9 \%$ \\
Effluent discharges & \multirow{2}{*}{$11.5 \%$} & Agriculture and forest phosphorus & $13.9 \%$ \\
& & BOD5 & $17.9 \%$ \\
& & COD & $32.5 \%$ \\
Land use $(+)$ & & Nitrogen & $25.4 \%$ \\
& \multirow{2}{*}{$56.9 \%$} & Phosphorus & $24.3 \%$ \\
& & pz_(AGR) & $10.9 \%$ \\
& & ed_(AGR) & $14.7 \%$ \\
& & ed_(ART) & $12.0 \%$ \\
& & ppc_(ART) & $14.0 \%$ \\
Land use $(-)$ & & shdi_(ALL) & $10.8 \%$ \\
& & cce_(ART)/(AGR) & $18.8 \%$ \\
& $22.7 \%$ & pz_(FOR) & $18.8 \%$ \\
& & ed_(FOR) & $44.5 \%$ \\
& & ppc_(FOR) & $12.8 \%$ \\
& & shdi_(FOR) & $33.8 \%$ \\
& & & $8.9 \%$
\end{tabular}

Intervention complexity

Effluent discharge sites

$20 \%$

Burned area

Slope

Strahler order

Population density

$20 \%$

ARB, Fig. 6(A), there are no catchments with the highest category. From the 248 catchments, 168 are classified according to the ecological status, while for the others, the Portuguese environmental agency assumes as unknown. The biggest part of the catchments is predominantly classified with a poor ecological status, while in the most upstream areas of the Ave and Vizela rivers, the status is good. According To the WFD, chemical status is classified as Good or Fail (Ternjej and Mihaljevic, 2017). In ARB, there are 107 catchments classified, and consistently verified that in the upstream areas of Ave and Vizela rivers, the classification is good, while in downstream is classified as fail. The $\operatorname{IPtI}_{N}$ measurements show some variations from the summer to winter in the twelve measurement sites, and generically, the highest values are found in the most upstream ARB areas. Fig. 7 demonstrates the assessment of CR through water quality data.
The boxplots presented in Fig. 7(A) show the data dispersion of CR according to the ecological status classification. It is noted that for the Good and Poor status, the range is considerably high, 0 to 0.7 and 0.1 to 0.75 , respectively. For the moderate status, the range is lower, 0.3 to 0.75 , and the bad category has the shortest range, 0.58 to 0.8 . In general is seen an increasing CR with the decrease of the ecological status classification since the average, median and 25-75 interquartile intervals along with the classifications. Only the poor status shows a deviation from this tendency since it has a lower median and average from the moderate and bad status. The good status has the lowest average median and quartiles 25 and 75. In contrast, the other categories have approached values, which visually indicates that the CR values only distinguish the good from the other categories. To confirm this hypothesis, it was applied the one-way-ANOVA test, proving that there is a difference between the classifications. Then, Tukey's test was applied, confirming that the "Good" is different from all the other statuses. The results are presented in the supplementary material. The chemical status, Fig. 7(B), shows that the range of CR is high in the good status, 0.05 to 0.8 , and lower for the Fail status, 0.3 to 0.82 . Still, the interquartile ranges are different and do not match, showing that the $C R$ is lower for the good status and higher for the fail classification. The ANOVA test was also performed for the CR and chemical status, checking that the two classes are different.

The $\mathrm{IPtI}_{\mathrm{N}}$ data was also compared to the CR. In Fig. 7(C) and (D), the scatter plots visually indicate that the $\mathrm{IPtI}_{\mathrm{N}}$ is associated with the $\mathrm{CR}$. Still, during the winter, the data is less dispersed than in the summer, with determination coefficients for a linear adjustment of $75.7 \%$ and $51.0 \%$, respectively. Both linear regressions are statistically significant for a confidence level of $95 \%$ since the $p$ values of $R^{2}$, intercept and slope are below 0.05 . The Pearson correlation between the $\operatorname{IPtI}_{\mathrm{N}}$ and CR for winter and summer are respectively 0.87 and 0.71 , significant for $p=0.001$ and $p=0.01$ (Daniel, 1998). Thus, the results show that the risk of contamination is associated with $\operatorname{IPtI}_{N}$ in both seasons, with a stronger association during the winter.

\subsection{Prioritization}

Contamination risk reveals the catchments that are mostly exposed to pollution sources according to the water quality parameters. The intention complexity analysis offered generic information about how easy it is to apply intervention strategies. By combining these two

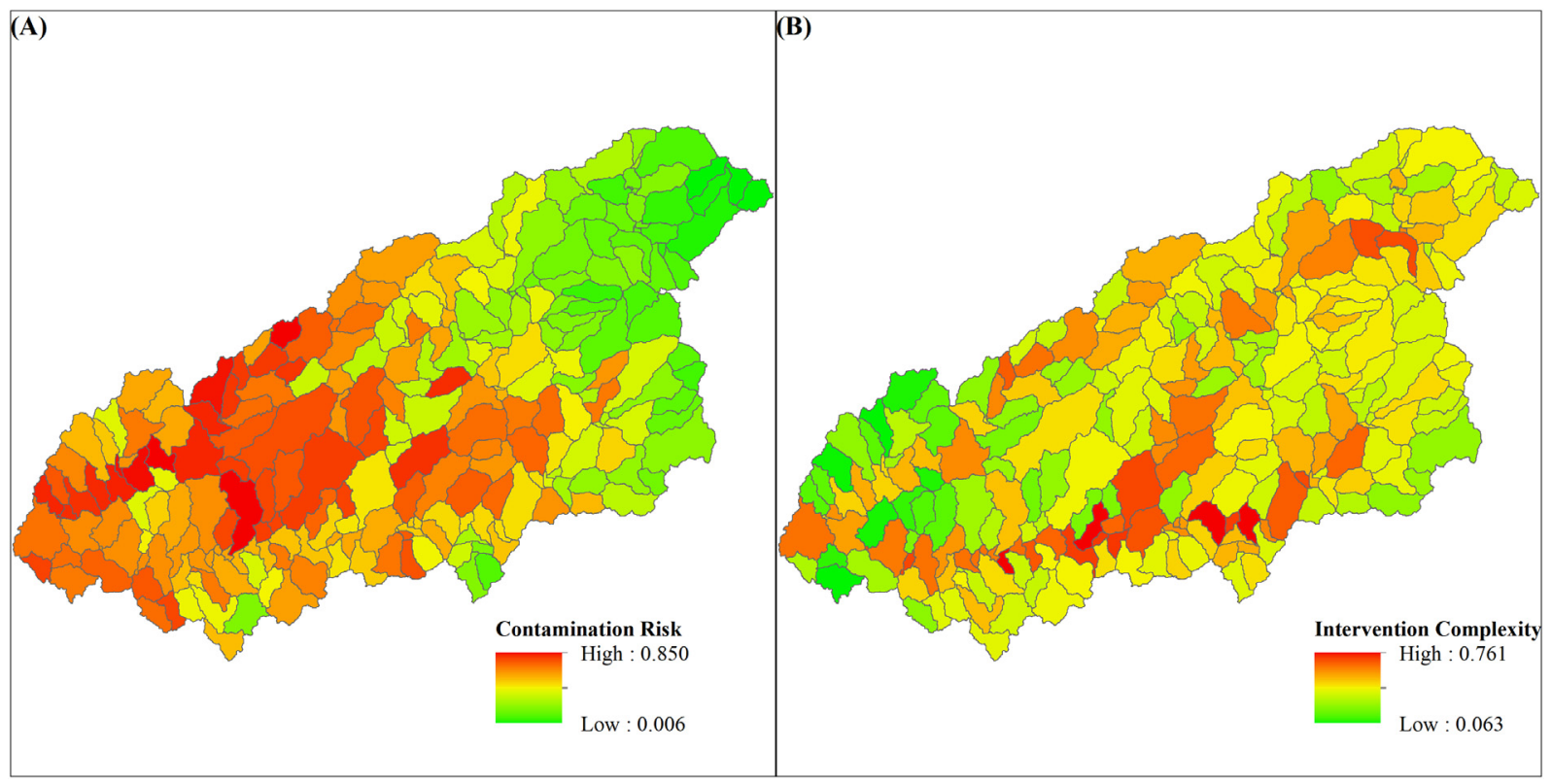

Fig. 5. Multicriteria analysis results, contamination risk in (A), and intervention complexity in (B). 


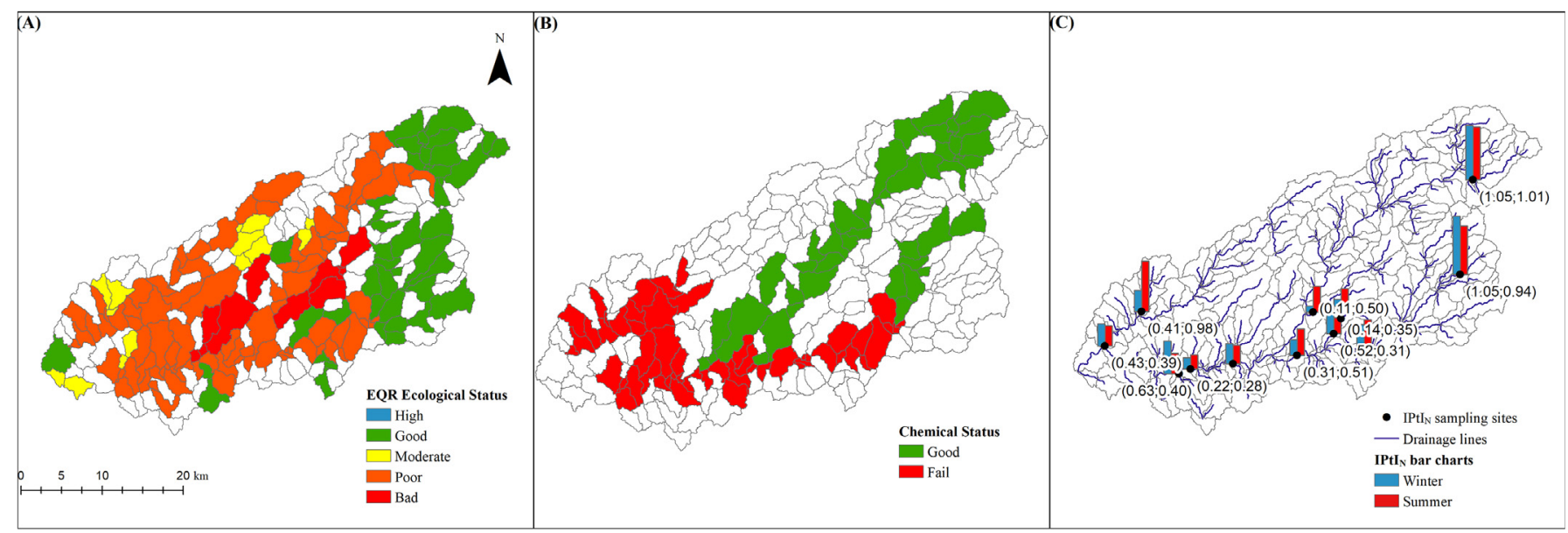

Fig. 6. Evaluation of Ave river basin water quality, according to APA, in (A) is for the EQR ecological status, in (B) for the chemical status and in (C) for the $\mathrm{IPtI}_{\mathrm{N}}$.

(A)

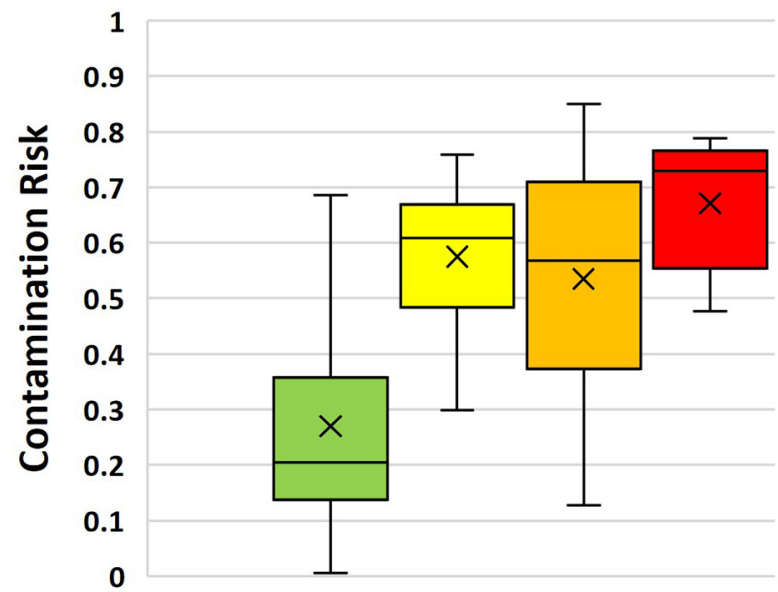

$\square$ High $\square$ Good $\square$ Moderate $\square$ Poor $\square$ Bad

(C)

Winter 2017

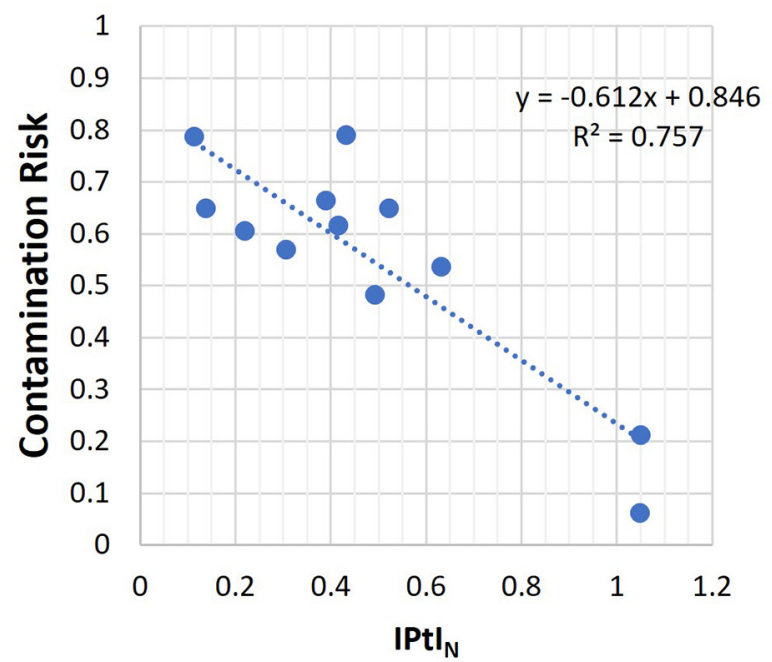

(B)

\section{Chemical Status}

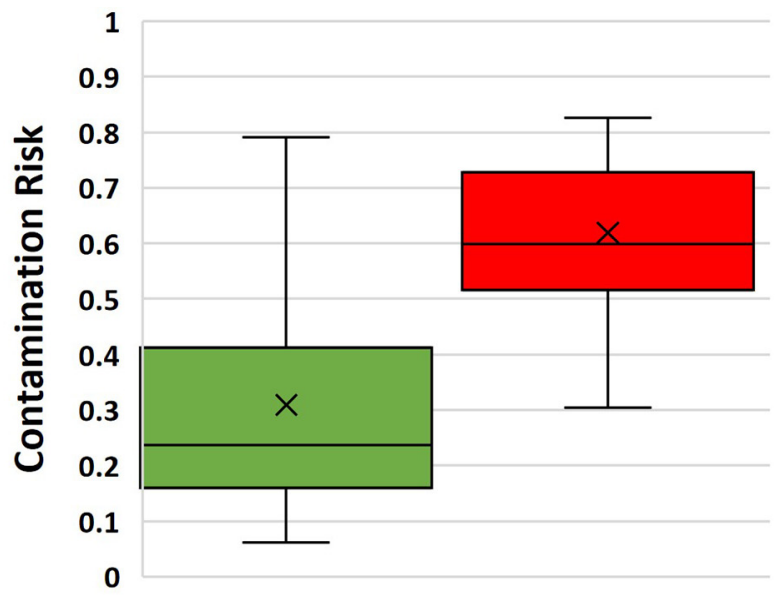

Good $\square$ Fail

(D)

\section{Summer 2017}

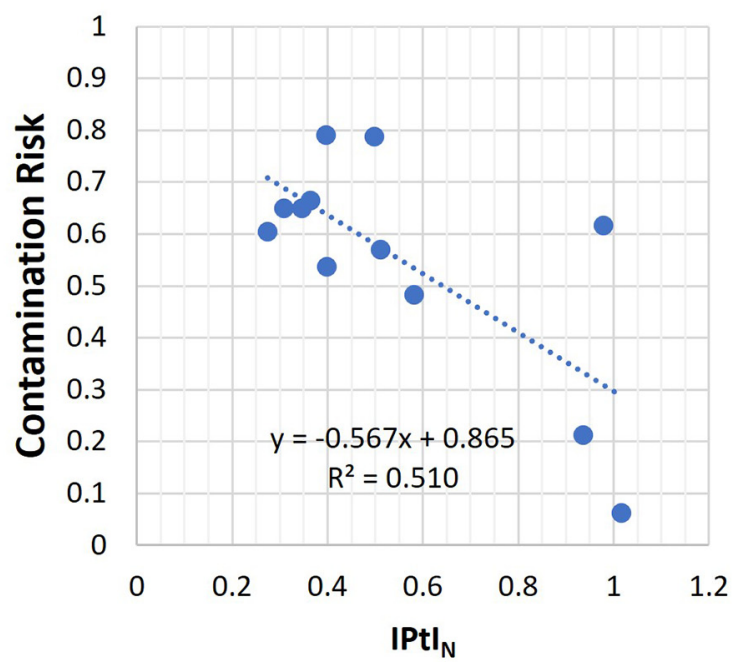

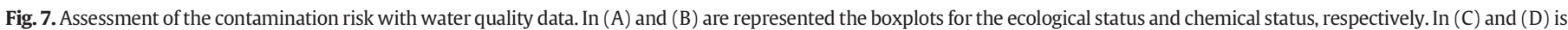
demonstrated the scatterplot of the $\operatorname{IPtI}_{\mathrm{N}}$, measured during winter and summer, respectively. 
concepts, it was ranked the prioritization of catchments for environmental interventions. By plotting the catchments in a two-dimension graph, the IC (vertical axis) and CR (horizontal axis) is given the dispersion of data. The catchments were subdivided into four quadrants, split by IC and CR average score, according to the prioritization category $1 \mathrm{st}$, 2nd, 3rd and 4th. To prioritize inside quadrants it was calculated the Euclidean distance to the preference point inside each quadrant (with minimum IC and maximum CR), and the catchments with the shortest distance have priority over the ones that have higher. This can be seen

(A)

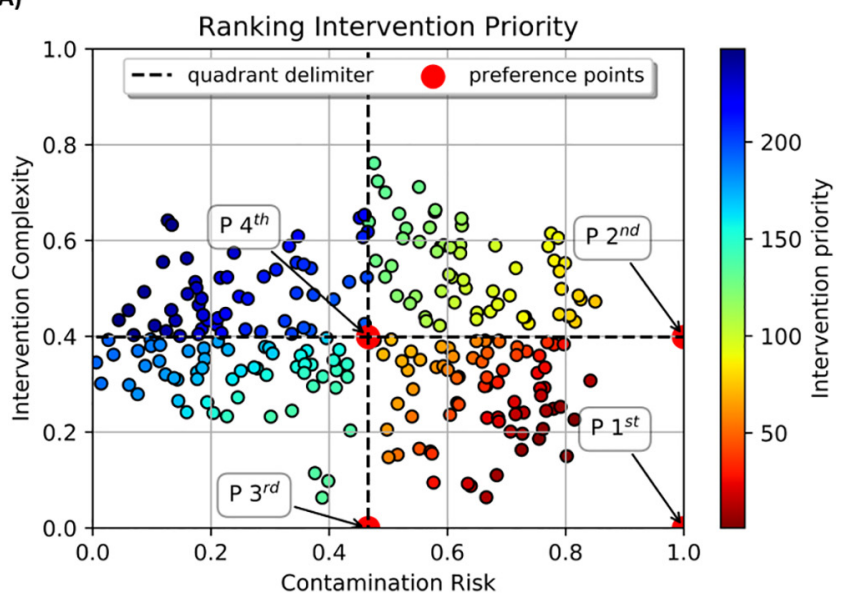

(B)

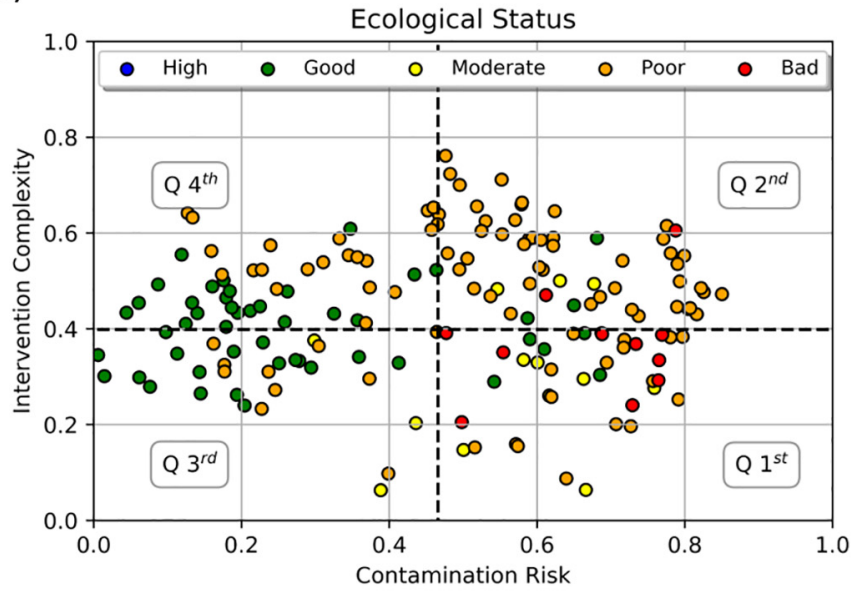

(C)

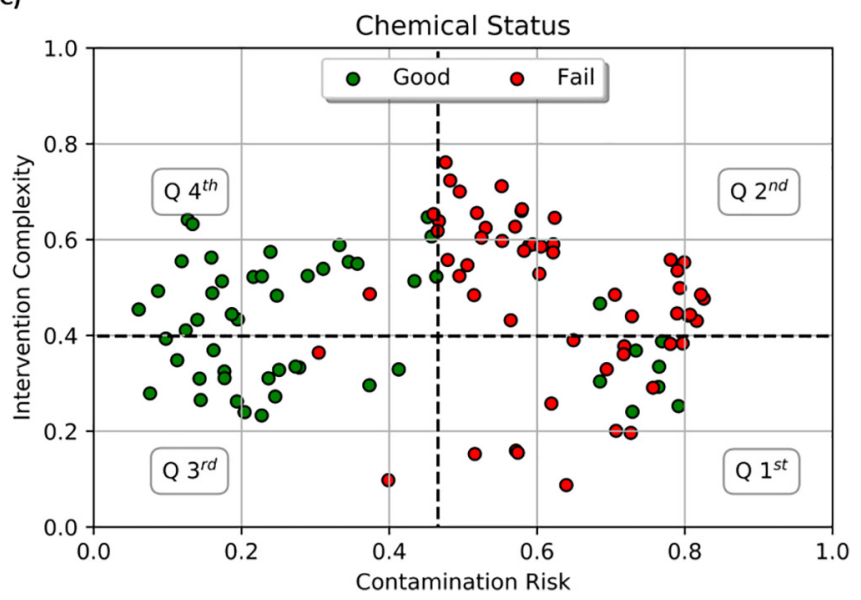

Fig. 8. Graphical analysis for the intervention procedure. In (A) is demonstrated for all catchments, while in (B) the catchments are coloured according to the ecological status, while in $(C)$ by the chemical status. in Fig. 8(A), where the catchments that are close to the respective preference point have a higher priority, according to the gradient colour. The spatial prioritization results are presented in Fig. 9. It is seen that exists a cluster of low priority catchments located in the upstream area of $\mathrm{ARB}$, while near to the outlet is predominantly occupied with high prioritization catchments.

According to Fig. 8(B) and (C), part of the catchments with a good ecological and chemical status are marked with a high intervention priority. This happens because the prioritization was based on a risk calculation. The presence of the risk does not mean that it exists poor water quality because the pressures might not be triggered to affect water quality. To analyze in detail Fig. 8 , it was created Table 2, where the quadrant classification is compared to the water quality status. It is seen that the biggest part of catchments with a good ecological and chemical status are placed in low priority quadrants, besides a small part is placed in high priority quadrants. For the low water quality categories is seen that the most considerable percentage is placed in the 1st and 2nd quadrants. But in the moderate ecological status the biggest part $57.1 \%$, is placed in the first, while for the poor, is placed half in the $2^{\text {nd }}$.

\section{Discussion}

The usage of models is essential to address water quality concerns (Acuña-Alonso et al., 2021). In ARB statistical (A. Fernandes et al., 2019a; A.C.P. Fernandes et al., 2019; Fernandes et al., 2018; Ferreira et al., 2017), and physical models (Fonseca et al., 2018) were applied to address water quality issues, which have a contribution in the water quality management by exposing cause-effect interactions of pollution sources and prediction of effects. Also is necessary to aim studies for risk assessment to ease environmental decision processes (Lyu et al., 2021), which is the main scope of this paper, prioritizing catchments for environmental interventions.

The choice of variables that compose $\mathrm{CR}$ was made according to previous studies. The impact of point source and diffuse emissions was exposed in SEM-PLS models for ARB (A.C.P. Fernandes et al., 2019; Fernandes et al., 2018). When these pressures were compared to landscape metrics, it was noted that land use can have a more significant influence on water quality (A. Fernandes et al., 2019a), which also happens in other Portuguese river basins (A. Fernandes et al., 2019b). For this reason, in the weighting procedure of $C R$, the land use criteria weights were higher than point-source and diffuse emissions. In previous studies, multiple landscape metrics were correlated with surface water parameters. More metrics are related to the increase rather than to the decrease of contamination (A.C.P. Fernandes et al., 2020b, 2020a). This resulted in the weight of $M+$ being greater than that of $\mathrm{M}-$. Metrics relative to agriculture and urban land uses are related to the decline of ecological integrity (A.C.P. Fernandes et al., 2020a, $2020 \mathrm{~b}$ ), but in terms of physicochemical properties, the metrics are associated with the increase of conductivity, total suspended solids, oxygen demands, and also different forms of nitrogen (A.C.P. Fernandes et al., 2020b).

The intervention complexity is not based directly on costs as other authors have studied (Gimeno et al., 2018; Privette et al., 2014), but linked to the concerning conditions that can hinder environmental interventions. Strahler order provides the hierarchical position for drainage lines/catchments within the river network (Strahler, 1957). As the Strahler order increases, the interactions along the river increase (Usseglio-Polatera and Beisel, 2002; Vannote et al., 1980), and also the flow and contaminant transport (Yang et al., 2019). For the same reason, it was chosen the number of effluent discharge sites, because the accumulation of effluents discharge sites increases intervention difficulty (Farhadian et al., 2019). Burned area is an important variable, particularly for Portugal, with a national concern for wildfires (Oliveira et al., 2021). Wildfires decrease water quality (Townsend and Douglas, 2004), but they can become an obstacle to any interventions of 


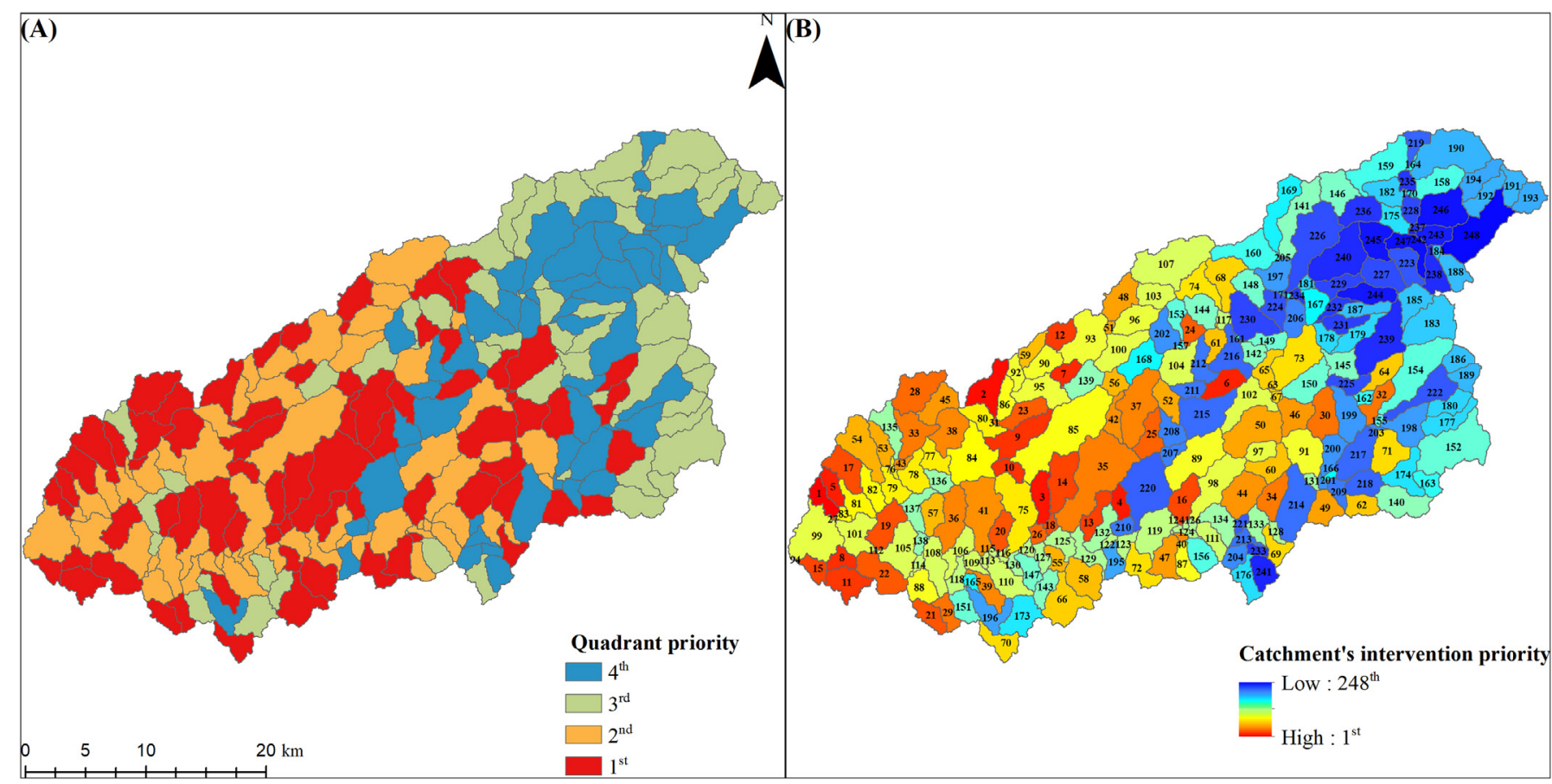

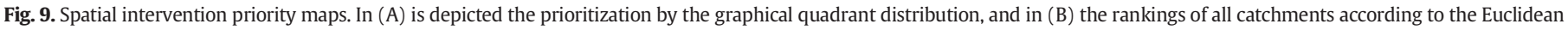
distance.

implementation of riparian vegetation (Tranmer et al., 2020) or in reforestation (Duffy et al., 2020; Shah and Nisbet, 2019). Any interventions that require the construction of structures or land-use changes are easier to apply in plain land than in hills. For this reason, the slope was implemented in the IC calculation. Areas with high slopes increase the diffuse emissions (Siqueira et al., 2017), but the application of interventions becomes more hampered with other aspects such as landslides (Ali et al., 2014), and the construction of adequate structures has increased costs (Li et al., 2019). For areas with high population density, the interventions become more challenging to apply due to urban areas (Wu and Murray, 2005). In such catchments, the interventions must be more careful due to the high number of inhabitants, and this might imply higher costs (Xie et al., 2021), especially with the inclusion of structures that bring social benefits (Logar et al., 2019).

The presented methodology can require an extensive data collection process but is simple to apply and can be replicated to other Portuguese river basins since the data sources contain data for the entire country. Even so, the authors alert that the application should not be applied to extensive areas, but ideally to entire catchments or in maximum for a single hydrographic region, since the phenomena that exist in a catchment can be different in another (Fernandes et al., 2018). For other countries, the methodology applicability is dependent on data availability. There are land-use maps and digital elevation models for all the regions around the globe. However, point source and diffuse emission data might not be accessible in all countries. For such cases, the contamination risk can be calculated only through landscape metrics, although the analysis might be incomplete. Also, the models can be adapted to

Table 2

Catchments prioritization vs water quality.

\begin{tabular}{|c|c|c|c|c|c|c|c|}
\hline \multirow[t]{2}{*}{ Quadrant } & \multicolumn{5}{|c|}{ Ecological } & \multicolumn{2}{|c|}{ Chemical } \\
\hline & High & Good & Moderate & Poor & Bad & Good & Fail \\
\hline $1 \mathrm{st}$ & $0.0 \%$ & $10.2 \%$ & $57.1 \%$ & $17.0 \%$ & $81.8 \%$ & $14.0 \%$ & $25.0 \%$ \\
\hline 2nd & $0.0 \%$ & $6.1 \%$ & $21.4 \%$ & $50.0 \%$ & $18.2 \%$ & $2.0 \%$ & $66.0 \%$ \\
\hline $3 r d$ & $0.0 \%$ & $36.7 \%$ & $21.4 \%$ & $10.6 \%$ & $0.0 \%$ & $35.0 \%$ & $4.0 \%$ \\
\hline 4th & $0.0 \%$ & $46.9 \%$ & $0.0 \%$ & $22.3 \%$ & $0.0 \%$ & $49.0 \%$ & $5.0 \%$ \\
\hline
\end{tabular}

the inclusion of other variables such as land use conflicts (Valle Junior et al., 2014), which affects other river basins (A. Fernandes et al., 2019b), or even different landscape metrics. The used weights in ARB should not be directly applied in a different case study. But the weighting scheme should always be calculated by experienced stakeholders or researchers who have conducted multiple water quality studies in the study site (Ruangpan et al., 2020).

The COVID-19 pandemic had immediate effects on water quality improvement due to the temporary closedown of industrial activities (Yunus et al., 2020). It is predicted that due to the pandemic, many countries are vulnerable to an economic crisis (Borio, 2020), which might lead to the permanent closedown of many industries. Consequently, the surface water quality might improve, as happened with other economic crises, such as the "Troika" years (A.C.P. Fernandes et al., 2019), but that is just in the short term. Ever since Portugal is impending an economic crisis (Tomé et al., 2020), hydric resources management might become compromised. Under a lower budget, intended interventions might even be impeded, so it is necessary to implement strategic and optimized intervention planning. In the latest updates of the WFD, 2021 and 2027 are the target years for achieving a good or higher ecological status in all European waters (Carvalho et al., 2019), which according to Fig. 6, seems a utopic scenario, at least for ARB. However is necessary to improve the ecological and chemical status as soon as possible, with efficient actions. In this sense, it is recommended for future studies to apply the presented methodology in other river basins, especially for those with poor water quality. Also, for the choice of possible interventions in each river basin/catchment is recommended to apply cost-effect analysis to choose optimal intervention strategies (McInnes et al., 2016; Schuwirth et al., 2018). This study highlights the necessity of bringing cross-sectorial coordination to come up with management actions to improve the ecological and chemical status (Paillex et al., 2017; Smiley et al., 2009), managing alternatives according to their contribution to enhance the quality of water, costs, and even relevant social objectives (Schuwirth et al., 2018).

In December of 2019, the APA launched a report for the HR relative to the 3rd cycle of the hydrographic region management plans (APA, 2019). Currently, a small part of the measures to improve water quality are concluded or pending to be applied, while the biggest part has not 
been yet performed. In terms of governance, many lacks exist in licensing, inspection, measurement, and control of discharges, which are classified as inefficient or insufficient. This might be the core reasons for ARB surface waters degradation. Still, the unground water of ARB is under a good chemical status, so it is necessary to apply remediation and preservation strategies for the surface water quality of ARB, ever since surface and groundwaters are linked (Martin, 2013). In the RBMP, a huge program of measures (PGRH, 2016b) is presented to fulfil environmental objectives according to the current Portuguese legislation and international accords. The available measures are prioritized according to the water quality status (PGRH, 2016b), which is a reasonable prioritization procedure. However, the developed methodology stands on the principle that the interventions should be prioritized in catchments with high contamination risk and low intervention complexity, to guarantee the feasibility of the applied interventions.

\subsection{Intervention guidelines}

The present methodology provides a geospatial description of intervention necessity through the risk analysis. By combining it with the intervention complexity, it provides an intervention priority of catchments. The authors recommend that the intervention procedures should be applied according to the intervention rankings depicted in Fig. 9. Still, before decision-makers decide to implement any interventions, it is recommended to apply a pre-intervention procedure that consists of monitoring the ecological and chemical status during three consecutive hydrological years, Fig. 10. It was chosen the ecological and chemical status since both are part of a holistic approach to address water quality, according to the WFD (Collins et al., 2012). The measurements should be made during the winter or summer periods, or preferable once during each season. During the monitoring, there are suggested three possible scenarios, Fig. 10. If the ecological status remains as good or higher and also the chemical as good, it means that there is no need to proceed with interventions, and then the monitoring frequency can be reduced. The worst scenario is when in two consecutive measurements, it is found that the ecological or chemical status is below a good classification. In that case, the authors consider that the implementation of interventions can start ever since the catchment has proved to be under low water quality. The other scenario is intermediate, consisting of observing that only one is below the good status over consecutive measurements. Under this circumstance is necessary to understand was caused by a continuous pollution source or if it was an isolated incident, such as a contaminant spill or a one-off effluent discharge that had high contaminant loads due to a system failure (Brown et al.,
2004). If it is an isolated incident, the monitoring should continue. Otherwise, interventions should proceed.

The possible interventions to improve water quality are multiple and should be considered according to the possible causes. The inspection of effluent discharges has not been adequately applied in Portugal due to the lack of resources (APA, 2019). Still, it is mandatory to improve monitoring and control and apply a penalty system (Ruiz-Rosa et al., 2020). With such practice, wastewater treatment stations will certainly enhance treatment technologies for sustainable contaminant emissions. Also, the Portuguese hydrographic management plans consider a revision of effluent emissions that can lead to a stricter regime of discharges rather than the currently applied (Decree-law no. 236/98). The construction of new wastewater treatment plants is also a solution, but it is a high-cost measure that only brings positive effects in the long term (Jajac et al., 2019). However, other innovative strategies can be applied, such as the reallocation of effluent discharge sites. Such a strategy improves quality, especially by decreasing oxygen demands (Farhadian et al., 2019). This type of approach requires physical modeling to choose new sites, which must not decrease the water quality of the new site significantly, but to provide a sustainable status, mitigating the most affected areas (Narr et al., 2019).

The sensibilization of courts for environmental crimes (Billiet et al., 2014) is a step forward for the application of efficient inspections and control. The strategy of the pollutant pays principle (Milon, 2019) is beneficial to the fulfilment of environmental requirements and prevents future environmental pollution due to the existence of a penalty (Mansyur et al., 2016). In another perspective, raising awareness of the environmental problems that the activities may cause is also beneficial to motivate stakeholders by the implementation of payments for ecosystems services (PES), which is a policy that might be more attractive rather than the polluter pay principle (Engel et al., 2008). This emerging policy solution works with the premise that communities or individuals are benefited from undertaking actions that improve ecosystem services (Farley and Costanza, 2010; Jacka et al., 2008). But still is necessary a continuous sensibilization of industries, farmers and livestock procedures to apply good and environmental practices, especially in the used products in their activities, to apply the best management practices (BMP) (Liu et al., 2017). For example, the sensibilization of farmers to use environmentally harmless pesticides and fertilizers to reduce diffuse emissions (Pearce and Yates, 2015). Nevertheless, the change and adaptation of sustainable habits are beneficial but still is necessary to construct structures that decrease the impact of nonpoint emissions. By resorting to urban ecosystem-based technologies (Everard and McInnes, 2013), loads of chemical contaminants from urban runoff can be reduced (Burant et al., 2018). For example, the

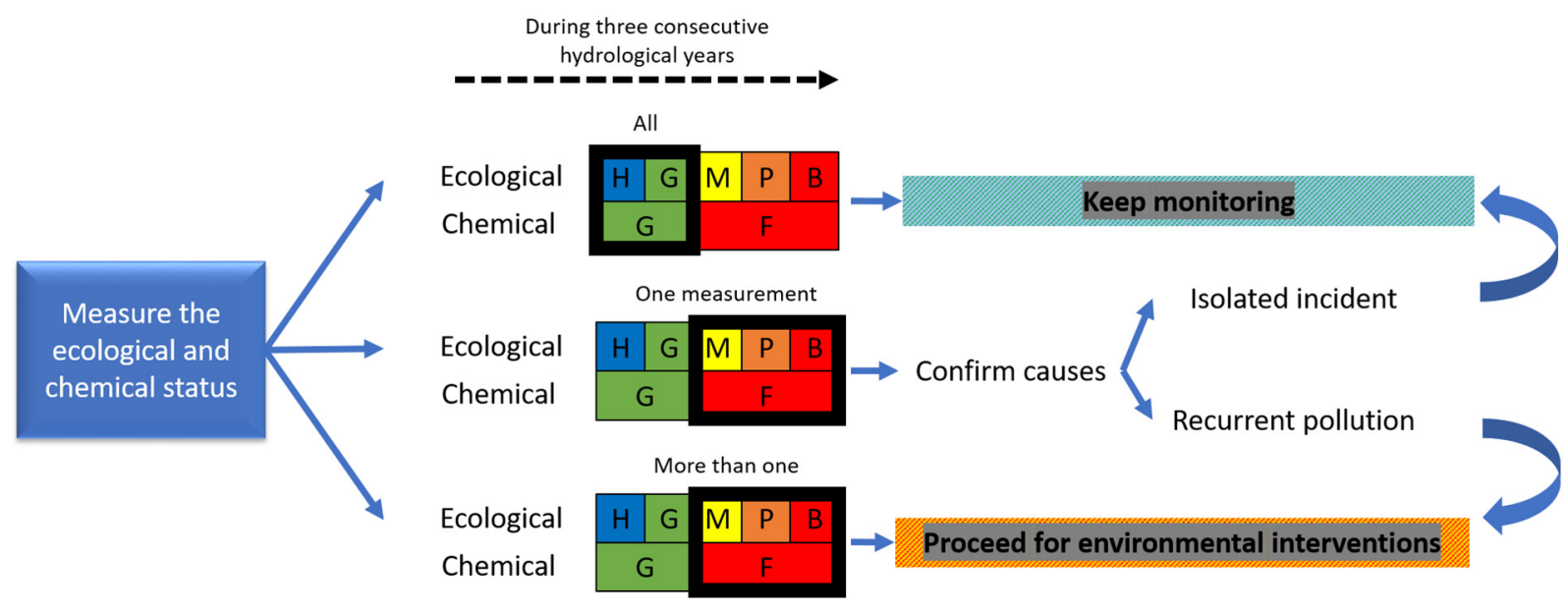

Fig. 10. Pre-intervention, monitoring procedure. 
Table 3

Intervention strategies.

\begin{tabular}{|c|c|c|c|c|}
\hline \multicolumn{4}{|c|}{$\begin{array}{l}\text { Preference on } \\
\text { quadrant priority }\end{array}$} & \multirow[t]{2}{*}{ Intervention strategies } \\
\hline 1 st & 2nd & 3rd & 4th & \\
\hline $\mathrm{x}$ & $\mathrm{x}$ & & & Promote inspection \\
\hline $\mathrm{x}$ & $\mathrm{x}$ & & & $\begin{array}{l}\text { Sensitizing the courts to environmental crimes as public } \\
\text { health crimes }\end{array}$ \\
\hline $\mathrm{x}$ & $\mathrm{x}$ & $\mathrm{x}$ & $\mathrm{x}$ & $\begin{array}{l}\text { Operationalization of an alert system against accidental } \\
\text { pollution cases }\end{array}$ \\
\hline $\mathrm{x}$ & $\mathrm{x}$ & $\mathrm{x}$ & $\mathrm{x}$ & $\begin{array}{l}\text { Assessment of potential sources of risk of accidental } \\
\text { pollution and assessment of safety reporting and emergency } \\
\text { plans }\end{array}$ \\
\hline $\mathrm{x}$ & $\mathrm{x}$ & $\mathrm{x}$ & $\mathrm{x}$ & Promotion of training and awareness of stakeholders actions \\
\hline $\mathrm{x}$ & $\mathrm{x}$ & $\mathrm{x}$ & $\mathrm{x}$ & $\begin{array}{l}\text { Sensitization of the various user sectors on the importance } \\
\text { of integrating water policies }\end{array}$ \\
\hline $\mathrm{x}$ & $\mathrm{x}$ & $\mathrm{x}$ & $\mathrm{x}$ & $\begin{array}{l}\text { Promotion of the application of the Code of Good } \\
\text { Agricultural Practices }\end{array}$ \\
\hline $\mathrm{x}$ & $\mathrm{x}$ & $\mathrm{x}$ & $\mathrm{x}$ & $\begin{array}{l}\text { Implementation of measures to raise awareness of the use of } \\
\text { phytopharmaceutical products }\end{array}$ \\
\hline & $\mathrm{x}$ & & $\mathrm{x}$ & Control urban sprawl \\
\hline $\mathrm{x}$ & & & & Construction of urban wastewater treatment plants \\
\hline & $\mathrm{x}$ & & & Refurbishment of urban wastewater treatment plants \\
\hline $\mathrm{x}$ & $\mathrm{x}$ & & & Refurbishment of industrial wastewater treatment plants \\
\hline & $\mathrm{x}$ & & $\mathrm{x}$ & $\begin{array}{l}\text { Recovery/repair of the urban wastewater and rainwater } \\
\text { network }\end{array}$ \\
\hline & $\mathrm{x}$ & & $\mathrm{x}$ & $\begin{array}{l}\text { Separation of public wastewater and rainwater drainage } \\
\text { networks }\end{array}$ \\
\hline $\mathrm{x}$ & & $\mathrm{x}$ & & $\begin{array}{l}\text { Install, maintain and recover riparian galleries and eradicate } \\
\text { invasive species in forest and agroforestry areas }\end{array}$ \\
\hline & $\mathrm{x}$ & & $\mathrm{x}$ & Valorization of sites of natural interest \\
\hline $\mathrm{x}$ & & $\mathrm{x}$ & & Natural restoration of rivers improving the riparian area \\
\hline $\mathrm{x}$ & & $\mathrm{x}$ & & Reforestation \\
\hline $\mathrm{x}$ & & $\mathrm{x}$ & & Implementation/improvement of washlands \\
\hline $\mathrm{x}$ & & $\mathrm{x}$ & & Construction of integrated wetlands \\
\hline & $\mathrm{x}$ & & $\mathrm{x}$ & Creation of Bioretention areas \\
\hline & $\mathrm{x}$ & & $\mathrm{x}$ & $\begin{array}{l}\text { Increases coverage of drainage infrastructures, particularly } \\
\text { in areas with industrial units }\end{array}$ \\
\hline & $\mathrm{x}$ & & $\mathrm{x}$ & Application of green roofs \\
\hline & $\mathrm{x}$ & & $\mathrm{x}$ & Implementation of permeable pavements \\
\hline $\mathrm{x}$ & & $\mathrm{x}$ & & Construction of swale systems \\
\hline $\mathrm{x}$ & & $\mathrm{x}$ & & Application of dry detention basins \\
\hline
\end{tabular}

application of green roofs can retain runoff volumes with retaining percentages above 50\% (Ahiablame et al., 2012), decreasing the dragged contaminant flow, which can retain nitrogen from runoff with a maximum percentage of $91 \%$ (Collins et al., 2010). But other less costly measures can be applied, for instance, permeable pavements, which reduces the emissions of other elements (for example, $\mathrm{Cu}, \mathrm{Pb}, \mathrm{Zn}$ ), over $81 \%$ (Dietz, 2007), and even the creation of bioretention areas, can significantly decrease urban runoff impacts (Liu et al., 2014). In agriculture/ livestock fields, the adoption of retaining methods of runoff flow is easier to apply rather than in urban regions since it is necessary to have a green area. The creation of dry retention basins attenuates peak flows, but in terms of quality, it is efficient in retaining total suspended solids and nutrients (Simpson and Weammert, 2009). Swale systems can be easily applied in agricultural fields. These structures can control and direction stormwaters flow and reduce the dispersion of contamination due to filtration phenomena (Ahmed et al., 2015). The application of integrated constructed wetlands (ICWs) can be effective in the reduction of contaminants (Everard and McInnes, 2013), even in antibiotics that result from livestock wastewater and can be viewed as a complementary treatment (F. Santos et al., 2019). The creation of washlands (Everard and McInnes, 2013) provides multi-benefits such as flood management, biodiversity promotion, which is also important to achieve a good ecological status (Wharton and Gilvear, 2007), but has the disadvantage that this can only be applied in large floodplains. The benefits of riparian vegetation on water quality are well known (Tabacchi et al., 2000), by controlling the runoff flow from soil to rivers. These structures can be easily applied when inexistent by resorting to ecological engineering procedures (L.F.S Fernandes et al., 2020), which allows the improvement of fluvial landscapes (Holgado et al., 2020), providing an ecosystem service. The improvement of riparian structures alerts to the beneficial effects that forestry can have on water quality (Duffy et al., 2020). According to the land use cover maps, ARB has been facing a continuous decrease of forest areas replaced mainly by agricultural and urban areas (DGTerritório, 2018). This alerts to the necessity of implementing strategies to control the urban sprawl (Habibi and Asadi, 2011), especially in the proximity to waterlines, which are a convenient basis for urban sprawl (Z. Li et al., 2020). At the same time is crucial to increase forested areas, which according to the Portuguese forest management plans (FMP), will be increased until 2045. These plans aim to conserve water and soil resources, decreasing contamination yields of nitrates up to 37\% (Pacheco et al., 2015). For such reasons, the increase of forested areas in ARB is a necessary measure, based on the principle that is in catchments with high forestry, that the best water quality can be found (Neary et al., 2009). Still, the implementation should be careful according to the complexity, ever since wildfires can destroy forested areas (Tonini et al., 2017).

This section demonstrated a resume of multiple measures that can be applied to improve ARB water quality, which is a guideline for decision-makers. Still, the authors believe that is crucial to apply the monitoring procedure that was presented in Fig. 10. It is believed that it might be impossible to monitor all the 248 catchments, so this is why the present methodology ranked the catchments to show the most critical catchments to apply interventions. Still, it is alerted that the development of the applied interventions in ARB should be continuously studied. According to all the intervention procedures referred in this section, is provided a list of interventions in Table 3, with also the spatial preference according to the quadrant ranking of catchments.

\section{Conclusion}

In Ave River Basin, located in the Northwest of Portugal, over 248 catchments were ranked according to surface water contamination risk. The analysis provided a rational classification that was statistically linked to the chemical and ecological status, which validated the assessment. Water quality data proved that in the river basin, multiple interventions must be applied to accomplish the WFD goals of achieving at least a good ecological and chemical status of all rivers until 2027. To support decision-makers, a decision process was developed based on the contamination risk and intervention complexity that prioritizes catchments for environmental interventions. This process is also dependent on future monitoring, which is a pivotal step to apply before the application of necessary interventions. Besides the presented methodology was applied to a single river basin, this study can be replicated to others, preferably in river basins that also face poor water quality. From the point of creating a stable and healthy environment, this work highlights the significance of thorough protection of the Ave River Basin. The spatial prioritization of catchments is an advisable guide for decision-makers that intend to safeguard the studied area hydric resources, intending to reduce the difficulty of choices and act where beneficial effects can be achieved.

\section{CRediT authorship contribution statement}

A.C.P. Fernandes: Conceptualization, Formal analysis, Investigation, Methodology, Software, Validation, Visualization, Writing - original draft, Writing - review \& editing. D.P.S. Terêncio: Formal analysis, Investigation, Methodology, Writing - review \& editing. F.A.L. Pacheco: Formal analysis, Funding acquisition, Methodology, Project administration, Resources, Supervision, Validation, Writing - review \& editing. L.F. Sanches Fernandes: Conceptualization, Formal analysis, Funding acquisition, Methodology, Project administration, Resources, Supervision, Writing - review \& editing. 


\section{Declaration of competing interest}

The authors declare that there are no conflicts of interest regarding the publication of this paper.

\section{Acknowledgements}

For authors integrated in the CITAB research centre, this work was supported by National Funds by FCT - Portuguese Foundation for Science and Technology, under the project UIDB/04033/2020. The authors integrated in the CITAB research centre are also integrated in the Inov4Agro - Institute for Innovation, Capacity Building and Sustainability of Agri-food Production. The Inov4Agro is an Associate Laboratory composed of two R\&D units (CITAB \& GreenUPorto). For the author integrated in the CQVR, the research was additionally supported by National Funds by FCT - Portuguese Foundation for Science and Technology, under the project UIDB/QUI/00616/2020 and UIDP/00616/2020. Financial support was provided by the Portuguese Foundation for Science and Technology (FCT), Ministry of Science, Technology, and Higher Education (MCTES), European Social Fund (FSE) through NORTE 2020 (North Regional Operational Program 2014/2020) and European Union (EU) to António Fernandes (Grant: SFRH/BD/146151/2019). The authors would like to thank the Regional Hydrographic Administration of the North (Administração Regional Hidrográfica do Norte, in Portuguese) and the Portuguese Environment Agency (Agência Portuguesa do Ambiente, in Portuguese) for providing the point source and diffuse emission data for Ave River Basin.

\section{Appendix A. Supplementary data}

Supplementary data to this article can be found online at https://doi. org/10.1016/j.scitotenv.2021.149322.

\section{References}

Acuña-Alonso, C., Fernandes, A.C.P., Álvarez, X., Valero, E., Pacheco, F.A.L., Varandas, S.D.G.P., Terêncio, D.P.S., Fernandes, L.F.S., 2021. Water security and watershed management assessed through the modelling of hydrology and ecological integrity: a study in the Galicia-costa (NW Spain). Sci. Total Environ. 759. https://doi.org/ 10.1016/j.scitotenv.2020.143905.

Adamczyk, J., Tiede, D., 2017. ZonalMetrics - a python toolbox for zonal landscape structure analysis. Comput. Geosci. 99, 91-99. https://doi.org/10.1016/J.CAGEO.2016.11.005.

Ahiablame, L.M., Engel, B.A., Chaubey, I., 2012. Effectiveness of low impact development practices: literature review and suggestions for future research. Water Air Soil Pollut. 223, 4253-4273. https://doi.org/10.1007/s11270-012-1189-2.

Ahmed, F., Gulliver, J.S., Nieber, J.L., 2015. Field infiltration measurements in grassed roadside drainage ditches: spatial and temporal variability. J. Hydrol. 530, 604-611. https://doi.org/10.1016/j.jhydrol.2015.10.012.

Ali, A., Huang, J., Lyamin, A.V., Sloan, S.W., Griffiths, D.V., Cassidy, M.J., Li, J.H., 2014. Simplified quantitative risk assessment of rainfall-induced landslides modelled by infinite slopes. Eng. Geol. 179, 102-116. https://doi.org/10.1016/j.enggeo.2014.06.024.

Alves, C., Boaventura, R., Soares, H., 2009. Evaluation of heavy metals pollution loadings in the sediments of the Ave River basin (Portugal). Soil Sediment Contam. 18, 603-618. https://doi.org/10.1080/15320380903113568.

Amporto, 2009. Rede de Parques Metropolitanos na Grande Área Metropolitana do Porto - Relatório Final - Anexo A - Sistemas Estruturantes: Ave.

Antwi-Agyei, P., Dougill, A.J., Stringer, L.C., 2017. Assessing coherence between sector policies and climate compatible development: opportunities for triple wins. Sustainability. 9. https://doi.org/10.3390/su9112130.

APA, 2019. Plano de Gestão da Região Hidrográfica Cávado, Ave e Leça (RH2) 3o Ciclo, Questões Significativas da Gestão da Água.

Araújo, M.F., Valério, P., Jouanneau, J.M., 1998. Heavy metal assessment in sediments of the Ave River Basin (Portugal) by energy-dispersive X-ray fluorescence spectrometry. X-Ray Spectrom. 27, 305-312. https://doi.org/10.1002/(SICI)1097-4539(199809/10) 27:5<305::AID-XRS275>3.0.CO;2-7.

Baker, A., 2003. Land use and water quality. Hydrol. Process. https://doi.org/10.1002/ hyp. 5140.

Benítez, R., Liern, V., 2021. Unweighted TOPSIS: a new multi-criteria tool for sustainability analysis. Int. J. Sustain. Dev. World Ecol. 28, 36-48. https://doi.org/10.1080/ 13504509.2020.1778583.

Billiet, C.M., Blondiau, T., Rousseau, S., 2014. Punishing environmental crimes: an empirical study from lower courts to the court of appeal. Regul. Gov. 8, 472-496. https:// doi.org/10.1111/rego.12044.

Borio, C., 2020. The Covid-19 economic crisis: dangerously unique. Bus. Econ. 55. https:// doi.org/10.1057/s11369-020-00184-2.
Brans, J.P., Mareschal, B., 2016. PROMETHEE methods. Int. Ser. Oper. Res. Manag. Sci. 233, 187-219. https://doi.org/10.1007/978-1-4939-3094-4_6.

Brown, R.A., Cornwell, D.A., Macphee, M.J., 2004. Trace contaminants in water treatment chemicals: sources and fate. J. Am. Water Work. Assoc. https://doi.org/10.1002/ j.1551-8833.2004.tb10763.x.

Burant, A., Selbig, W., Furlong, E.T., Higgins, C.P., 2018. Trace organic contaminants in urban runoff: associations with urban land-use. Environ. Pollut. 242, 2068-2077. https://doi.org/10.1016/j.envpol.2018.06.066.

Carvalho, L., Mackay, E.B., Cardoso, A.C., Baattrup-Pedersen, A., Birk, S., Blackstock, K.L., Borics, G., Borja, A., Feld, C.K., Ferreira, M.T., Globevnik, L., Grizzetti, B., Hendry, S., Hering, D., Kelly, M., Langaas, S., Meissner, K., Panagopoulos, Y., Penning, E., Rouillard, J., Sabater, S., Schmedtje, U., Spears, B.M., Venohr, M., van de Bund, W., Solheim, A.L., 2019. Protecting and restoring Europe's waters: an analysis of the future development needs of the water framework directive. Sci. Total Environ. 658, 1228-1238. https://doi.org/10.1016/j.scitotenv.2018.12.255.

Collins, A., Ohandja, D.G., Hoare, D., Voulvoulis, N., 2012. Implementing the Water Framework Directive: A transition from established monitoring networks in England and Wales. Environ. Sci. Policy https://doi.org/10.1016/j.envsci.2011.11.003.

Collins, K.A., Lawrence, T.J., Stander, E.K., Jontos, R.J., Kaushal, S.S., Newcomer, T.A., Grimm, N.B., Cole Ekberg, M.L., 2010. Opportunities and challenges for managing nitrogen in urban stormwater: a review and synthesis. Ecol. Eng. 36, 1507-1519. https://doi.org/ 10.1016/j.ecoleng.2010.03.015.

Conley, D.J., Paerl, H.W., Howarth, R.W., Boesch, D.F., Seitzinger, S.P., Havens, K.E., Lancelot, C., Likens, G.E., 2009. Ecology - controlling eutrophication: nitrogen and phosphorus. Science https://doi.org/10.1126/science.1167755.

Costa, F., 2008. Hidro-conflitos na bacia hidrográfica do rio Ave - uma análise a partir das transgressões cometidas no período 1902-1973, Actas do XI Colóquio Ibérico de Geografia.

Couto, C., Ribeiro, C., Maia, A., Santos, M., Tiritan, E., Pinto, A., Pinto, E., Almeida, A., 2018. Assessment of Douro and Ave River (Portugal) lower basin water quality focusing on physicochemical and trace element spatiotemporal changes. J. Environ. Sci. Health A 53 (12), 1056-1066. https://doi.org/10.1080/10934529.2018.1474577.

Daniel, L.G., 1998. Statistical significance testing: a historical overview of misuse and misinterpretation with implications for the editorial policies of educational journals. Res. Sch. Res. Sch. Mid-South Educ. Res. Assoc. 5, 23-32.

De Montis, A., De Toro, P., Droste-Franke, B., Omann, I., Stagl, S., 2004. Assessing the quality of different MCDA methods. Alternatives for Environmental Valuation, pp. 99-133 https://doi.org/10.4324/9780203412879-14.

Delpla, I., Jung, A.V., Baures, E., Clement, M., Thomas, O., 2009. Impacts of climate change on surface water quality in relation to drinking water production. Environ. Int. https://doi.org/10.1016/j.envint.2009.07.001.

Destouni, G., Fischer, I., Prieto, C., 2017. Water quality and ecosystem management: datadriven reality check of effects in streams and lakes. Water Resour. Res. 53, 6395-6406. https://doi.org/10.1002/2016WR019954.

DGTerritório, 2018. The 2015 Map of Occupation and Land Use (Carta de Uso e Ocupação do Solo in Portuguese) [WWW Document].

Dietz, M.E., 2007. Low impact development practices: A review of current research and recommendations for future directions. Water Air Soil Pollut. https://doi.org/ 10.1007/s11270-007-9484-z.

Duffy, C., O'Donoghue, C., Ryan, M., Kilcline, K., Upton, V., Spillane, C., 2020. The impact of forestry as a land use on water quality outcomes: an integrated analysis. For. Policy Econ. 116. https://doi.org/10.1016/j.forpol.2020.102185.

Dunck, B., Lima-Fernandes, E., Cássio, F., Cunha, A., Rodrigues, L., Pascoal, C., 2015. Responses of primary production, leaf litter decomposition and associated communities to stream eutrophication. Environ. Pollut. https://doi.org/10.1016/j. envpol.2015.03.014.

Dwivedi, S., Shikha, D., 2016. Water pollution: Causes, effects and control. Biochem. Cell. Arch. 16.

EC, 2000. Directive 2000/60/EC of the European Parliament and of the Council of 23 October 2000 establishing a framework for Community action in the field of water policy. Off. J. Eur. Parliam, L327 https://doi.org/10.1039/ap9842100196.

EEA, 2021. Data and maps - European Environment Agency [WWW Document]. URL. https://www.eea.europa.eu/data-and-maps (accessed 12.12.18).

Engel, S., Pagiola, S., Wunder, S., 2008. Designing payments for environmental services in theory and practice: an overview of the issues. Ecol. Econ. 65, 663-674. https://doi. org/10.1016/j.ecolecon.2008.03.011.

ESRI, 2012. ArcHydro Tools for ArcGIS 10 - Tutorial.

ESRI, 2010. ArcMap (Version 10).

Everard, M., McInnes, R., 2013. Systemic solutions for multi-benefit water and environmental management. Sci. Total Environ. 461-462, 170-179. https://doi.org/ 10.1016/j.scitotenv.2013.05.010.

Farhadian, M., Bozorg-Haddad, O., Pazoki, M., Loáiciga, H.A., 2019. Minimal adverse impact of discharging polluted effluents to rivers with selective locations. Sustain. Cities Soc. 46, 101394. https://doi.org/10.1016/j.scs.2018.12.022.

Farley, J., Costanza, R., 2010. Payments for ecosystem services: from local to global. Ecol. Econ. 69, 2060-2068. https://doi.org/10.1016/j.ecolecon.2010.06.010.

Fernandes, A., Fernandes, L.F.S., Cortes, R.M.V., Pacheco, F.A.L., 2019a. The role of landscape configuration, season, and distance from contaminant sources on the degradation of stream water quality in urban catchments. Water (Switzerland) 11, 20-25. https://doi.org/10.3390/w11102025.

Fernandes, A., Sanches Fernandes, L.F., Terêncio, D.P.S., Cortes, R.M.V., Pacheco, F.A.L., 2019b. Seasonal and scale effects of anthropogenic pressures on water quality and ecological integrity: a study in the Sabor River basin (NE Portugal) using partial least squares-path modeling. Water https://doi.org/10.3390/w11091941. 
Fernandes, A.C.P., Martins, L.M.O., Fernandes, L.F.S., Cortes, R.M.V., Pacheco, F.A.L., 2020a. Exploring the effects of landscape metrics in water quality, Ave river basin case study. Int. J. Des. Nat. Ecodyn. 15, 65-72. https://doi.org/10.18280/ijdne.150109.

Fernandes, A.C.P., Martins, L.M.O., Fernandes, L.F.S., Cortes, R.M.V., Pacheco, F.A.L., 2020b. Effect of landscape metrics on water quality over three decades: a case study of the Ave River basin,\&nbsp;Portugal. WIT Trans. Ecol. Environ. 242, 39-49. https://doi. org/10.2495/WP200041.

Fernandes, A.C.P., Sanches Fernandes, L.F., Moura, J.P., Cortes, R.M.V., Pacheco, F.A.L., 2019. A structural equation model to predict macroinvertebrate-based ecological status in catchments influenced by anthropogenic pressures. Sci. Total Environ. 681, 242-257. https://doi.org/10.1016/J.SCITOTENV.2019.05.117.

Fernandes, L.F.S., Fernandes, A.C.P., Ferreira, A.R.L., Cortes, R.M.V., Pacheco, F.A.L., 2018. A partial least squares - path modeling analysis for the understanding of biodiversity loss in rural and urban watersheds in Portugal. Sci. Total Environ. 626, 1069-1085. https://doi.org/10.1016/J.SCITOTENV.2018.01.127.

Fernandes, L.F.S., Pinto, A.A.S., Terêncio, D.P.S., Pacheco, F.A.L., Cortes, R.M.V., 2020. Combination of ecological engineering procedures applied to morphological stabilization of estuarine banks after dredging. Water (Switzerland) 12. https://doi.org/10.3390/ w12020391.

Fernandes, M.R., Aguiar, F.C., Ferreira, M.T., 2011. Assessing riparian vegetation structure and the influence of land use using landscape metrics and geostatistical tools. Landsc. Urban Plan. https://doi.org/10.1016/j.landurbplan.2010.11.001.

Ferreira, A.R.L., Sanches Fernandes, L.F., Cortes, R.M.V., Pacheco, F.A.L., 2017. Assessing anthropogenic impacts on riverine ecosystems using nested partial least squares regression. Sci. Total Environ. 583, 466-477. https://doi.org/10.1016/j.scitotenv. 2017.01.106.

Fonseca, A., Boaventura, R.A.R., Vilar, V.J.P., 2018. Integrating water quality responses to best management practices in Portugal. Environ. Sci. Pollut. Res. https://doi.org/ 10.1007/s11356-017-0610-1.

Fonseca, A.R., Santos, J.A., 2019. Predicting hydrologic flows under climate change: the Tâmega Basin as an analog for the Mediterranean region. Sci. Total Environ. 668, 1013-1024. https://doi.org/10.1016/j.scitotenv.2019.01.435.

Fonseca, A.R., Santos, J.A., 2018. High-resolution temperature datasets in Portugal from a geostatistical approach: variability and extremes. J. Appl. Meteorol. Climatol. 57, 627-644. https://doi.org/10.1175/JAMC-D-17-0215.1.

Francisco, C.E.da S., Coelho, R.M., Torres, R.B., Adami, S.F., 2008. Watershed selection for environmental rehabilitation using multicriteria analysis. Cienc. Florest. 18, 1-13. https://doi.org/10.5902/19805098506.

Gimeno, P., Severyns, J., Acuña, V., Comas, J., Corominas, L., 2018. Balancing environmental quality standards and infrastructure upgrade costs for the reduction of microcontaminant loads in rivers. Water Res. 143, 632-641. https://doi.org/ 10.1016/j.watres.2018.07.002.

Goepel, K.D., 2013. Implementing the Analytic Hierarchy Process as a Standard Method for Multi-criteria Decision Making in Corporate Enterprises - A New AHP Excel Template With Multiple Inputs. https://doi.org/10.13033/isahp.y2013.047.

Gonçalves, E.P.R., Boaventura, R.A.R., Mouvet, C., 1992. Sediments and aquatic mosses as pollution indicators for heavy metals in the Ave river basin (Portugal). Sci. Total Environ. https://doi.org/10.1016/0048-9697(92)90410-T.

Govindan, K., Jepsen, M.B., 2016. ELECTRE: A comprehensive literature review on methodologies and applications. Eur. J. Oper. Res. https://doi.org/10.1016/j.ejor.2015. 07.019 .

Guadie, A., Yesigat, A., Gatew, S., Worku, A., Liu, W., Minale, M., Wang, A., 2021. Effluent quality and reuse potential of urban wastewater treated with aerobic-anoxic system: a practical illustration for environmental contamination and human health risk assessment. J. Water Process Eng. 40. https://doi.org/10.1016/j.jwpe.2020.101891.

Habibi, S., Asadi, N., 2011. Causes, results and methods of controlling urban sprawl. Procedia Engineering https://doi.org/10.1016/j.proeng.2011.11.1996.

Hagemann, S., Blome, T., Saeed, F., Stacke, T., 2014. Perspectives in modelling climatehydrology interactions. Surv. Geophys. https://doi.org/10.1007/s10712-013-9245-Z.

Holgado, P.M., Rieth, L.J., Menárguez, A.B.B., Álvarez, F.A., 2020. The analysis of urban fluvial landscapes in the centre of Spain, their characterization, values and interventions. Sustainability 12. https://doi.org/10.3390/su12114661.

Huang, I.B., Keisler, J., Linkov, I., 2011. Multi-criteria decision analysis in environmental sciences: ten years of applications and trends. Sci. Total Environ. https://doi.org/ 10.1016/j.scitotenv.2011.06.022.

ICNF, 2021. Informação Geográfica [WWW Document]. URL. https://geocatalogo.icnf.pt/ (accessed 12.20.20)

INAG, 2009. Critérios para a Classificação do Estado das Massas de Água Superficiais - Rios e Albufeiras, Critérios para a classificação do estado das massas de água superficiais rios e 697 albufeiras. Technical Report [in Portuguese]. Ministério do Ambiente, do Ordenamento do 698 Território e do Desenvolvimento Regional, Instituto da Água, IP. INE, 2014. Censos 2011 [WWW Document]. https://censos.ine.pt/.

Ippolito, A., Kattwinkel, M., Rasmussen, J.J., Schäfer, R.B., Fornaroli, R., Liess, M., 2015. Modeling global distribution of agricultural insecticides in surface waters. Environ. Pollut. 198, 54-60. https://doi.org/10.1016/j.envpol.2014.12.016.

Jacka, B.K., Kouskya, C., Simsa, K.R.E., 2008. Designing payments for ecosystem services: Lessons from previous experience with incentive-based mechanisms. Proc. Natl. Acad. Sci. U. S. A. https://doi.org/10.1073/pnas.0705503104.

Jajac, N., Marovic, I., Rogulj, K., Kilic, J., 2019. Decision support concept to selection of wastewater treatment plant location-the case study of town of Kutina, Croatia. Water (Switzerland) 11. https://doi.org/10.3390/w11040717.

Jayasumana, C., Fonseka, S., Fernando, A., Jayalth, K., Amarasinghe, M., Paranagma, P., 2014. Presence of arsenic in agrochemicals and their association with the agricultural chronic kidney disease in Sri Lanka. J. Toxicol. Health 104, 352-361.
Johnson, L.B., Richards, C., Host, G.E., Arthur, J.W., 1997. Landscape influences on water chemistry in Midwestern stream ecosystems. Freshw. Biol. https://doi.org/10.1046/ j.1365-2427.1997.d01-539.x.

Karkman, A., Do, T.T., Walsh, F., Virta, M.P.J., 2018. Antibiotic-resistance genes in waste water. Trends Microbiol. https://doi.org/10.1016/j.tim.2017.09.005.

Kazakis, N., Matiatos, I., Ntona, M.M., Bannenberg, M., Kalaitzidou, K., Kaprara, E., Mitrakas, M., Ioannidou, A., Vargemezis, G., Voudouris, K., 2020. Origin, implications and management strategies for nitrate pollution in surface and ground waters of anthemountas basin based on a d15N-NO3- and d180-NO3- isotope approach. Sci. Total Environ. 724. https://doi.org/10.1016/j.scitotenv.2020.138211.

Khatri, N., Tyagi, S., 2015. Influences of natural and anthropogenic factors on surface and groundwater quality in rural and urban areas. Front. Life Sci. 8, 23-39. https://doi.org/ 10.1080/21553769.2014.933716

Krapivin, V.F., Mkrtchan, F.A., Varotsos, C.A., Xue, Y., 2021. Operational diagnosis of Arctic waters with instrumental technology and information modeling. Water Air Soil Pollut. 232. https://doi.org/10.1007/s11270-021-05068-5.

Krapivin, V.F., Varotsos, C.A., Nghia, B.Q., 2017. A modeling system for monitoring water quality in lagoons. Water Air Soil Pollut. 228. https://doi.org/10.1007/s11270-0173581-4.

Lang, S., Tiede, D., 2003. vLATE Extension für ArcGIS - vektorbasiertes Tool zur quantitativen Landschaftsstrukturanalyse. ESRI European User Conference 2003 Innsbruck. CDROM, pp. 1-10.

László, B., Szilágyi, F., Szilágyi, E., Heltai, G., Licskó, I., 2007. Implementation of the EU water framework directive in monitoring of small water bodies in Hungary, I. establishment of surveillance monitoring system for physical and chemical characteristics for small mountain watercourses. Microchem. J. 85, 65-71. https://doi.org/10.1016/j. microc.2006.06.007.

Lee, S.W., Hwang, S.J., Lee, S.B., Hwang, H.S., Sung, H.C., 2009. Landscape ecological approach to the relationships of land use patterns in watersheds to water quality characteristics. Landsc. Urban Plan. 92, 80-89. https://doi.org/10.1016/j.landurbplan. 2009.02.008

Li, H., Chen, H., Li, X., Zhang, F., 2019. Design and construction application of concrete canvas for slope protection. Powder Technol. 344, 937-946. https://doi.org/10.1016/j. powtec.2018.12.075.

Li, W., Lei, O., Yen, H., Wollheim, W.M., Zhai, L., Hu, W., Zhang, L., Qiu, W., Luo, J., Wang, H., Ren, T., Liu, H., 2020. The overlooked role of diffuse household livestock production in nitrogen pollution at the watershed scale. J. Clean. Prod. 272. https://doi.org/10.1016/ j.jclepro.2020.122758.

Li, Z., Luan, W., Zhang, Z., Su, M., 2020. Relationship between urban construction land expansion and population/economic growth in Liaoning Province,\&nbsp;China. Land Use Policy 99, 105022. https://doi.org/10.1016/j.landusepol.2020.105022.

Lima, W.de P., 2008. Princípios de Hidrologia Florestal para Manejo de Bacias Hidrográficas. FEALQ, Piracicaba.

Liu, J., Sample, D.J., Bell, C., Guan, Y., 2014. Review and research needs of bioretention used for the treatment of urban stormwater. Water (Switzerland) https://doi.org/10.3390/ w6041069.

Liu, Y., Engel, B.A., Flanagan, D.C., Gitau, M.W., McMillan, S.K., Chaubey, I., 2017. A review on effectiveness of best management practices in improving hydrology and water quality: Needs and opportunities. Sci. Total Environ. https://doi.org/10.1016/j. scitotenv.2017.05.212.

Logar, I., Brouwer, R., Paillex, A., 2019. Do the societal benefits of river restoration outweigh their costs? A cost-benefit analysis. J. Environ. Manag. 232, 1075-1085. https://doi.org/10.1016/j.jenvman.2018.11.098.

Loucks, D.P., van Beek, E., 2017. Water Resource Systems Planning and Management: An Introduction to Methods, Models, and Applications. https://doi.org/10.1007/978-3319-44234-1.

Lyu, H.M., Zheng, Q., Shen, S.L., Zhou, A., 2021. Method for a new risk assessment of urban water quality: IFN-SPA. MethodsX 8. https://doi.org/10.1016/j.mex.2021.101237.

Malczewski, J., 2010. Multiple criteria decision analysis and geographic information systems. International Series in Operations Research and Management Science, pp. 369-395 https://doi.org/10.1007/978-1-4419-5904-1_13.

Mansyur, C.L., Jeng, H.A., Holloman, E., De Brew, L., 2016. Using community-based participatory research to identify environmental justice issues in an inner-city community and inform urban planning. Fam. Community Health 39, 169-177. https://doi.org/ 10.1097/FCH.0000000000000110.

Martin, J., 2013. Rivers and Streams. Hydro-environmental Analysis. CRC Press, pp. 13-14 https://doi.org/10.1201/b16108-3.

Martins, J., Rocha, A., Viceto, C., Pereira, S.C., Santos, J.A., 2020. Future projections for wind, wind shear and helicity in the Iberian Peninsula. Atmosphere (Basel). 11. https://doi. org/10.3390/atmos11091001.

McInnes, R., Smith, G., Greaves, J., Watson, D., Wood, N., Everard, M., 2016. Multicriteria decision analysis for the evaluation of water quality improvement and ecosystem service provision. Water Environ. J. 30, 298-309. https://doi.org/10.1111/wej.12195.

Mehta, L., 2014. Water and human development. World Dev. 59, 59-69. https://doi.org 10.1016/j.worlddev.2013.12.018

Mellander, P.E., Jordan, P., Shore, M., Melland, A.R., Shortle, G., 2015. Flow paths and phosphorus transfer pathways in two agricultural streams with contrasting flow controls. Hydrol. Process. 29, 3504-3518. https://doi.org/10.1002/hyp.10415.

Mello, K., Costa, D.R., Valente, R.A., Vettorazzi, C.A., 2018. Multicriteria evaluation for protected area definition aiming at water quality improvement. Floresta e Ambient 25. https://doi.org/10.1590/2179-8087.013416.

Mentzafou, A., Panagopoulos, Y., Dimitriou, E., 2019. Designing the national network for automatic monitoring of water quality parameters in Greece. Water (Switzerland) 11. https://doi.org/10.3390/w11061310. 
Miller, W., 2019. Food, water, energy, waste: an examination of socio-technical issues for urban prosumers - part 1 (context). Energy Procedia https://doi.org/10.1016/j. egypro.2019.02.104.

Milon, J.W., 2019. The polluter pays principle and Everglades restoration. J. Environ. Stud. Sci. 9, 67-81. https://doi.org/10.1007/s13412-018-0529-y.

Mockler, E.M., Deakin, J., Archbold, M., Gill, L., Daly, D., Bruen, M., 2017. Sources of nitrogen and phosphorus emissions to Irish rivers and coastal waters: Estimates from a nutrient load apportionment framework. Sci. Total Environ. https://doi.org/10.1016/ j.scitotenv.2017.05.186.

Murphy, F., Ewins, C., Carbonnier, F., Quinn, B., 2016. Wastewater Treatment Works (WwTW) as a source of microplastics in the aquatic environment. Environ. Sci. Technol. https://doi.org/10.1021/acs.est.5b05416.

Murray, A.T., 2002. GIS and multicriteria decision analysis, by Jacek Malczewski, 1999. Geogr. Anal. 34, 91-92. https://doi.org/10.1111/j.1538-4632.2002.tb01077x.

Narr, C.F., Singh, H., Mayer, P., Keeley, A., Faulkner, B., Beak, D., Forshay, K.J., 2019. Quantifying the effects of surface conveyance of treated wastewater effluent on groundwater, surface water, and nutrient dynamics in a large river floodplain. Ecol. Eng. 129. https://doi.org/10.1016/j.ecoleng.2018.12.030.

Nas, S.S., Nas, E., 2009. Water quality modeling and dissolved oxygen balance in streams: a point source Streeter-Phelps application in the case of the Harsit stream. Clean - Soil Air Water https://doi.org/10.1002/clen.200800107.

Neary, D.G., Ice, G.G., Jackson, C.R., 2009. Linkages between forest soils and water quality and quantity. For. Ecol. Manag. 258, 2269-2281. https://doi.org/10.1016/J. FORECO.2009.05.027

Nilsson, C., Svedmark, M., 2002. Basic principles and ecological consequences of changing water regimes: riparian plant communities. Environ. Manag. https://doi.org/10.1007/ s00267-002-2735-2.

Ofosu, S.A., Adjei, K.A., Odai, S.N., 2020. Ecological vulnerability of the Densu river basin due to land use change and climate variability. Cogent Eng. 7. https://doi.org/ 10.1080/23311916.2020.1735714.

Oliveira, S., Gonçalves, A., Zêzere, J.L., 2021. Reassessing wildfire susceptibility and hazard for mainland Portugal. Sci. Total Environ. 762, 143121. https://doi.org/10.1016/j. scitotenv.2020.143121.

Pacheco, F.A.L., Martins, L.M.O., Quininha, M., Oliveira, A.S., Sanches Fernandes, L.F., 2018. An approach to validate groundwater contamination risk in rural mountainous catchments: the role of lateral groundwater flows. MethodsX 5, 1447-1455. https://doi. org/10.1016/j.mex.2018.11.002.

Pacheco, F.A.L., Santos, R.M.B., Sanches Fernandes, L.F., Pereira, M.G., Cortes, R.M.V., 2015. Controls and forecasts of nitrate yields in forested watersheds: a view over mainland Portugal. Sci. Total Environ. 537, 421-440. https://doi.org/10.1016/j.scitotenv. 2015.07.127.

Pahl-Wostl, C., 2007. Transitions towards adaptive management of water facing climate and global change. Water Resour. Manag., 49-62 https://doi.org/10.1007/s11269006-9040-4.

Paillex, A., Reichert, P., Lorenz, A.W., Schuwirth, N., 2017. Mechanistic modelling for predicting the effects of restoration, invasion and pollution on benthic macroinvertebrate communities in rivers. Freshw. Biol. 62, 1083-1093. https://doi.org/10.1111/ fwb.12927.

Pascoal, C., Cássio, F., Marvanová, L., 2005a. Anthropogenic stress may affect aquatic hyphomycete diversity more than leaf decomposition in a low-order stream. Arch. Hydrobiol. 162, 481-496. https://doi.org/10.1127/0003-9136/2005/0162-0481.

Pascoal, C., Marvanová, L., Cássio, F., 2005b. Aquatic hyphomycete diversity in streams of Northwest Portugal. Fungal Divers. 19, 109-128. https://doi.org/10.1007/s00442005-0300-4.

Pascoal, C., Pinho, M., Cássio, F., Gomes, P., 2003. Assessing structural and functional ecosystem condition using leaf breakdown: studies on a polluted river. Freshw. Biol. https://doi.org/10.1046/j.1365-2427.2003.01130.x.

Pearce, N.J.T., Yates, A.G., 2015. Agricultural best management practice abundance and location does not influence stream ecosystem function or water quality in the summer season. Water (Switzerland) 7, 6861-6876. https://doi.org/10.3390/w7126661.

Peixoto, F.P., Carrola, J., Coimbra, A.M., Fernandes, C., Teixeira, P., Coelho, L., Conceição, I., Oliveira, M.M., Fontaínhas-Fernandes, A., 2013. Oxidative stress responses and histological hepatic alterations in barbel, Barbus bocagei, from Vizela River,\&nbsp; Portugal. Rev. Int. Contam. Ambient. 29, 29-38.

Pérez Andrés, N., Martínez Santa-María, C., Fernández Yuste, J., 2019. Are wastewater treatment plants modifying our rivers? Cuadernos de la Sociedad Española de Ciencias Forestales 1 (45), 157-169.

PGRH, 2016a. Plano De Gestão Da Região Hidrográfica Do Cávado Ave e Leça Resumo Não técnico, 20 ciclo. ed.

PGRH, 2016b. Plano De Gestão Da Região Hidrográfica Do Cávado Ave e Leça Relatório Base Parte 6- Programas e Medidas, 20 ciclo. ed

Privette, C.V., Taylor, S.W., Hayes, J.C., Hallo, L.S., Nix, H.B., 2014. Costs associated with mitigating the impacts on water quality of future development within the Reedy River watershed using various best management practices. Ecol. Eng. 71, 326-334. https://doi.org/10.1016/j.ecoleng.2014.07.030.

Raines, G.L., 2002. Description and comparison of geologic maps with FRAGSTATS - a spatial statistics program. Comput. Geosci. 28, 169-177. https://doi.org/10.1016/S00983004(01)00030-9.

Rattan, K.J., Bowes, M.J., Yates, A.G., Culp, J.M., Chambers, P.A., 2020. Evaluating diffuse and point source phosphorus inputs to streams in a cold climate region using a load apportionment model. J. Great Lakes Res. https://doi.org/10.1016/j.jglr.2020.05.003.

Reid, A.J., Carlson, A.K., Creed, I.F., Eliason, E.J., Gell, P.A., Johnson, P.T.J., Kidd, K.A., MacCormack, T.J., Olden, J.D., Ormerod, S.J., Smol, J.P., Taylor, W.W., Tockner, K., Vermaire, J.C., Dudgeon, D., Cooke, S.J., 2019. Emerging threats and persistent conservation challenges for freshwater biodiversity. Biol. Rev. 94, 849-873. https://doi.org/ 10.1111/brv.12480.
Rempel, R., Kaukinen, D., Carr, A., 2012. Ontario Minist. Nat. Resour. Cent. North. For. Ecosyst. Res, Thunder Bay, Ontario http://www.cnfer.on.ca/SEP/.

Ribeiro, C.M.R., Maia, A.S., Ribeiro, A.R., Couto, C., Almeida, A.A., Santos, M., Tiritan, M.E. 2016. Anthropogenic pressure in a Portuguese river: endocrine-disrupting compounds, trace elements and nutrients. J. Environ. Sci. Health - Part A Toxic/Hazard. Subst. Environ. Eng. https://doi.org/10.1080/10934529.2016.1198622.

Rocha, M.J., Cruzeiro, C., Rocha, E., 2013. Quantification of 17 endocrine disruptor compounds and their spatial and seasonal distribution in the Iberian Ave River and its coastline. Toxicol. Environ. Chem. 95, 386-399. https://doi.org/10.1080/ 02772248.2013.773002.

Ruangpan, L., Vojinovic, Z., Plavšic, J., Doong, D.J., Bahlmann, T., Alves, A., Tseng, L.H., Randelovic, A., Todorovic, A., Kocic, Z., Beljinac, V., Wu, M.H., Lo, W.C., Perez-Lapeña, B., Franca, M.J., 2020. Incorporating stakeholders\&apos; preferences into a multicriteria framework for planning large-scale nature-based solutions. Ambio https:// doi.org/10.1007/s13280-020-01419-4.

Ruiz-Rosa, I., García-Rodríguez, F.J., Antonova, N., 2020. Developing a methodology to recover the cost of wastewater reuse: a proposal based on the polluter pays principle. Util. Policy 65. https://doi.org/10.1016/j.jup.2020.101067.

Russo, R.D.F.S.M., Camanho, R., 2015. Criteria in AHP: A systematic review of literature. Procedia Computer Science, pp. 1123-1132 https://doi.org/10.1016/j.procs.2015. 07.081 .

Saaty, T., 2008. Decision making with the analytic hierarchy process. Int. J. Serv. Sci. 1, $83-98$.

Saaty, T.L., 1980. The analytical hierarchy process, planning, priority. Priority Setting. Resource Allocation. MacGraw-Hill, New York International Book Company.

Santos, F., Almeida, C.M.R., Ribeiro, I., Mucha, A.P., 2019. Potential of constructed wetland for the removal of antibiotics and antibiotic resistant bacteria from livestock wastewater. Ecol. Eng. 129, 45-53. https://doi.org/10.1016/j.ecoleng.2019.01.007.

Santos, M., Fonseca, A., Fragoso, M., Santos, J.A., 2019. Recent and future changes of precipitation extremes in mainland Portugal. Theor. Appl. Climatol. https://doi.org/ $10.1007 /$ s00704-018-2667-2.

Schiff, R., Benoit, G., 2007. Effects of impervious cover at multiple spatial scales on coastal watershed streams. J. Am. Water Resour. Assoc. https://doi.org/10.1111/j.17521688.2007.00057.x.

Schuwirth, N., Honti, M., Logar, I., Stamm, C., 2018. Multi-criteria decision analysis for integrated water quality assessment and management support. Water Res. X 1. https:// doi.org/10.1016/j.wroa.2018.100010.

Shah, N.W., Nisbet, T.R., 2019. The effects of forest clearance for peatland restoration on water quality. Sci. Total Environ. 693, 133617. https://doi.org/10.1016/j. scitotenv.2019.133617.

Simpson, T., Weammert, S., 2009. Developing Best Management Practice Definitions and Effectiveness Estimates for Nitrogen, Phosphorus and Sediment in the Chesapeake Bay Watershed, p. 822.

Siqueira, H.E., Pissarra, T.C.T., do Valle Junior, R.F., Fernandes, L.F.S., Pacheco, F.A.L., 2017. A multi criteria analog model for assessing the vulnerability of rural catchments to road spills of hazardous substances. Environ. Impact Assess. Rev. https://doi.org/10.1016/j. eiar.2017.02.002.

Skoulikaris, C., Zafirakou, A., 2019. River Basin management plans as a tool for sustainable transboundary river basins\&apos; management. Environ. Sci. Pollut. Res. 26, 14835-14848. https://doi.org/10.1007/s11356-019-04122-4.

Smiley, P.C., Gillespie, R.B., King, K.W., Huang, C., hua, 2009. Management implications of the relationships between water chemistry and fishes within channelized headwater streams in the midwestern United States. Ecohydrology 2, 294-302. https://doi.org/ $10.1002 /$ eco. 51.

SNIAMB, 2016. Sistema Nacional de Informação de Ambiente [WWW Document]. URL. https://sniamb.apambiente.pt/ (accessed 12.2.20).

Soares, H.M.V.M., Boaventura, R.A.R., Machado, A.A.S.C., Esteves Da Silva, J.C.G., 1999. Sediments as monitors of heavy metal contamination in the ave river basin (Portugal): multivariate analysis of data. Environ. Pollut. 105, 311-323. https://doi.org/10.1016/ S0269-7491(99)00048-2.

Sousa, J.C.G., Barbosa, M.O., Ribeiro, A.R.L., Ratola, N., Pereira, M.F.R., Silva, A.M.T., 2020. Distribution of micropollutants in estuarine and sea water along the Portuguese coast. Mar. Pollut. Bull. 154, 111120. https://doi.org/10.1016/j.marpolbul. 2020.111120.

Spycher, S., Mangold, S., Doppler, T., Junghans, M., Wittmer, I., Stamm, C., Singer, H., 2018 Pesticide risks in small streams - how to get as close as possible to the stress imposed on aquatic organisms. Environ. Sci. Technol. 52, 4526-4535. https://doi.org/10.1021/ acs.est.8b00077.

Strahler, A.N., 1957. Quantitative analysis of watershed geomorphology. EOS Trans. Am. Geophys. Union 38. https://doi.org/10.1029/TR038i006p00913.

Tabacchi, E., Lambs, L., Guilloy, H., Planty-Tabacchi, A.M., Muller, E., Décamps, H., 2000. Impacts of riparian vegetation on hydrological processes. Hydrol. Process. 14 2959-2976 doi:.

Terêncio, D.P.S., Fernandes, L.F.S., Cortes, R.M.V., Moura, J.P., Pacheco, F.A.L., 2020. Flood risk attenuation in critical zones of continental Portugal using sustainable detention basins. Sci. Total Environ. 721. https://doi.org/10.1016/j.scitotenv.2020.137727.

Terêncio, D.P.S., Fernandes, L.F.S., Cortes, R.M.V., Moura, J.P., Pacheco, F.A.L., 2019. Can land cover changes mitigate large floods? A reflection based on partial least squares-path modeling. Water (Switzerland) 11, 684. https://doi.org/10.3390/w11040684.

Terêncio, D.P.S., Pacheco, F.A.L., Sanches Fernandes, L.F., Cortes, R.M.V., 2021. Is it safe to remove a dam at the risk of a sprawl by exotic fish species? Sci. Total Environ. 771. https://doi.org/10.1016/j.scitotenv.2020.144768.

Terêncio, D.P.S., Sanches Fernandes, L.F., Cortes, R.M.V., Pacheco, F.A.L., 2017. Improved framework model to allocate optimal rainwater harvesting sites in small watersheds for agro-forestry uses. J. Hydrol. 550, 318-330. https://doi.org/10.1016/j.jhydrol. 2017.05.003. 
Ternjej, I., Mihaljevic, Z., 2017. Ecology. Phys. Sci. Rev. 2. https://doi.org/10.1515/psr2016-0116.

Thakur, A.K., 2012. Model: mechanistic vs empirical. New Trends in Pharmacokinetics https://doi.org/10.1007/978-1-4684-8053-5_3.

Saaty, Thomas L., 2000. Fundamentals of Decision Making and Priority Theory. 2nd edition. RWS Publications.

Tomé, E., Gromova, E., Hatch, A., 2020. Did the bubble Burst? The portuguese economy during COVID-19. Manag. Mark. 15. https://doi.org/10.2478/mmcks-2020-0028.

Tonini, M., Pereira, M.G., Parente, J., Vega Orozco, C., 2017. Evolution of forest fires in Portugal: from spatio-temporal point events to smoothed density maps. Nat. Hazards 85, 1489-1510. https://doi.org/10.1007/s11069-016-2637-X.

Townsend, S.A., Douglas, M.M., 2004. The effect of a wildfire on stream water quality and catchment water yield in a tropical savanna excluded from fire for 10 years (Kakadu National Park, North Australia). Water Res. https://doi.org/10.1016/j.watres.2004. 04.009.

Tranmer, A.W., Benjankar, R., Tonina, D., 2020. Post-wildfire riparian forest recovery processes along a regulated river corridor. For. Ecol. Manag. 478, 118513. https://doi.org/ 10.1016/j.foreco.2020.118513.

Usseglio-Polatera, P., Beisel, J.N., 2002. Longitudinal changes in macroinvertebrate assemblages in the Meuse River: anthropogenic effects versus natural change. River Res. Appl. 18, 197-211. https://doi.org/10.1002/rra.651.

Uuemaa, E., Roosaare, J., Mander, Ü., 2007. Landscape metrics as indicators of river water quality at catchment scale. Hydrology Research 38 (2), 125-138. https://doi.org/ 10.2166/nh.2007.002.

Valle Junior, R.F., Varandas, S.G.P., Sanches Fernandes, L.F., Pacheco, F.A.L., 2014. Environmental land use conflicts: a threat to soil conservation. Land Use Policy 41, 172-185. https://doi.org/10.1016/J.LANDUSEPOL.2014.05.012.

Vannote, R.L., Minshall, G.W., Cummins, K.W., Sedell, J.R., Cushing, C.E., 1980. The river continuum concept. Can. J. Fish. Aquat. Sci. https://doi.org/10.1139/f80-017.

Varotsos, C.A., Krapivin, V.F., 2019. Modeling the state of marine ecosystems: a case study of the Okhotsk Sea. J. Mar. Syst. 194, 1-10. https://doi.org/10.1016/j.jmarsys. 2019.02.003.

Varotsos, C.A., Krapivin, V.F., 2018. Pollution of Arctic waters has reached a critical point: an innovative approach to this problem. Water Air Soil Pollut. 229. https://doi.org/ 10.1007/s11270-018-4004-X.

Varotsos, C.A., Krapivin, V.F., Mkrtchyan, F.A., 2019. New optical tools for water quality diagnostics. Water Air Soil Pollut. 230. https://doi.org/10.1007/s11270-019-4228-4.

Varotsos, C.A., Krapivin, V.F., Mkrtchyan, F.A., Gevorkyan, S.A., Cui, T., 2020. A novel approach to monitoring the quality of lakes water by optical and modeling tools: Lake Sevan as a case study. Water Air Soil Pollut. 231. https://doi.org/10.1007/s11270020-04792-8.

Varotsos, C.A., Krapivin, V.F., Mkrtchyan, F.A., Xue, Y., 2021. Optical spectral tools for diagnosing water media quality: a case study on the angara/yenisey river system in the siberian region. Land 10. https://doi.org/10.3390/land10040342.

de Vasconcelos, A.S.B., 2015. Estudo da qualidade da água do Rio Ave: relevância da relação entre indicadores macroinvertebrados e parâmetros físico-químicos. University of Porto MSc Thesis (in Portuguese).

Vörösmarty, C.J., Green, P., Salisbury, J., Lammers, R.B., 2000. Global water resources: vulnerability from climate change and population growth. Science https://doi.org/ 10.1126/science.289.5477.284.

Voza, D., Vukovic, M., Takic, L., Nikolic, D., Mladenovic-Ranisavljevic, I., 2015. Application of multivariate statistical techniques in the water quality assessment of Danube river, Serbia. Arch. Environ. Prot. 41, 96-103. https://doi.org/10.1515/aep-2015-0044.
Warrington, B.M., Aust, W.M., Barrett, S.M., Ford, W.M., Dolloff, C.A., Schilling, E.B., Wigley, T.B., Bolding, M.C., 2017. Forestry best management practices relationships with aquatic and riparian fauna: a review. Forests https://doi.org/10.3390/f8090331.

Wharton, G., Gilvear, D.J., 2007. River restoration in the UK: meeting the dual needs of the European Union water framework directive and flood defence? Int. J. River Basin Manag. 5, 143-154. https://doi.org/10.1080/15715124.2007.9635314.

Withers, P.J.A., Jarvis, S.C., 1998. Mitigation options for diffuse phosphorus loss to water. Soil Use Manag. 14, 186-192. https://doi.org/10.1111/j.1475-2743.1998.tb00638.x.

Wittmer, I.K., Bader, H.P., Scheidegger, R., Singer, H., Lück, A., Hanke, I., Carlsson, C., Stamm, C., 2010. Significance of urban and agricultural land use for biocide and pesticide dynamics in surface waters. Water Res. 44, 2850-2862. https://doi.org/ 10.1016/j.watres.2010.01.030.

Wu, C., Murray, A.T., 2005. A cokriging method for estimating population density in urban areas. Comput. Environ. Urban. Syst. 29. https://doi.org/10.1016/j.compenvurbsys. 2005.01.006.

Wu, J., Lu, J., 2021. Spatial scale effects of landscape metrics on stream water quality and their seasonal changes. Water Res. 191. https://doi.org/10.1016/j.watres.2021. 116811.

Xie, X., Fang, B., Xu, H., He, S., Li, X., 2021. Study on the coordinated relationship between urban land use efficiency and ecosystem health in China. Land Use Policy 102, 105235. https://doi.org/10.1016/j.landusepol.2020.105235.

Yang, S., Büttner, O. Kumar, R., Jäger, C., Jawitz, JW., Rao, P. S.C., Borchardt, D. 2019. Spatial patterns of water quality impairments from point source nutrient loads in Germany\&apos;s largest national River Basin (Weser River). Sci. Total Environ. 697. https://doi.org/10.1016/j.scitotenv.2019.134145.

Yu, S., Xu, Z., Wu, W., Zuo, D., 2016. Effect of land use types on stream water quality under seasonal variation and topographic characteristics in the Wei River basin, China. Ecol. Indic. 60, 202-212. https://doi.org/10.1016/J.ECOLIND.2015.06.029.

Yu, X., Zhang, S., Liao, X., Oi, X., 2018. ELECTRE methods in prioritized MCDM environment. Inf. Sci. (N. Y.) 424. https://doi.org/10.1016/j.ins.2017.09.061.

Yunus, A.P., Masago, Y., Hijioka, Y., 2020. COVID-19 and surface water quality: improved lake water quality during the lockdown. Sci. Total Environ. 731. https://doi.org/ 10.1016/j.scitotenv.2020.139012.

Zaragozí, B., Belda, A., Linares, J., Martínez-Pérez, J.E., Navarro, J.T., Esparza, J., 2012. A free and open source programming library for landscape metrics calculations. Environ. Model. Softw. 31, 131-140. https://doi.org/10.1016/j.envsoft.2011.10.009.

Zhang, J., Li, S., Dong, R., Jiang, C., Ni, M., 2019. Influences of land use metrics at multispatial scales on seasonal water quality: a case study of river systems in the Three Gorges Reservoir area, China. J. Clean. Prod. 206, 76-85. https://doi.org/10.1016/J. JCLEPRO.2018.09.179.

Zhang, Y., Long, H., Li, Y., Tu, S., Jiang, T., 2020. Non-point source pollution in response to rural transformation development: a comprehensive analysis of China\&apos;s traditional farming area. J. Rural. Stud. https://doi.org/10.1016/j.jrurstud.2020.10.010.

Zhao, J., Yang, K., Tai, J., Shan, F., 2011. Review of the relationship between regional landscape pattern and surface water quality. Shengtai Xuebao/Acta Ecol. Sin 31 (11), 3180-3189.

Zörb, C., Senbayram, M., Peiter, E., 2014. Potassium in agriculture-status and perspectives. J. Plant Physiol. https://doi.org/10.1016/j.jplph.2013.08.008. 